\title{
Coins and Cosmologies in Iron Age Western Britain
}

\begin{tabular}{|r|l|}
\hline Journal: & Cambridge Archaeological Journal \\
\hline Manuscript ID & CAJ-AR-2017-0074.R1 \\
\hline Manuscript Type: & Research Article \\
\hline Date Submitted by the Author: & 29-Apr-2018 \\
\hline Complete List of Authors: & Pudney, Caroline; University of Chester, History and Archaeology \\
\hline Manuscript Keywords: & Iron Age, Coins, Cosmology, material culture \\
\hline
\end{tabular}

SCHOLARONE $^{\text {m }}$

Manuscripts 


\title{
Coins and Cosmologies in Iron Age Western Britain
}

\begin{abstract}
This paper offers a material culture-based approach to British Western Iron Age coins (i.e. those often attributed to the Dobunni). Through analysis of the materiality and imagery of these objects the author explores the embodiment of later Iron Age cosmologies. In doing so the cycles of day and night, and of life and death are discussed. The ways in which these cosmologies could have been transposed onto the landscape through coin production and depositional contexts helps to demonstrate how Iron Age societies in Western Britain may have understood their world and confirmed their space within it.
\end{abstract}

Key words: Iron Age; coins; cosmology; material culture

\section{Introduction}

This speculative paper aims to pose some different approaches to Iron Age coins, specifically that of the British Western coinage. This is an exciting field, with huge quantities of data and in which the groundwork has already been done by generations of numismatists. Building on their work and the new and innovative approaches to material culture, there is much scope for further analysis and discussion of Iron Age coins from Britain which in turn, will help us better understand later prehistoric human-object relationships. For example, dominated by images of human heads and horses, the imagery on British Western Iron Age or 'Dobunnic' coins can be approached as evidence for human-horse relationships in parts of western Britain. In a previous article, the author has argued that the imagery on coins can help us understand the dynamic between humans and horses and the importance of horses in Iron Age lives, especially when considered in conjunction with horse-related metalwork and the treatment of faunal remains (Pudney2018).

In this article, the author aims to explore how specifically the other imagery found upon British Western issue coins may also help us discover relationships between people and other aspects of the environment and the role of these objects therein. Although inspiration for coin design largely derives from the coins of Philip II of Macedon, where the head of Apollo is situated on the obverse and a horse and rider on the reverse: the chariot of the sun god (Allen 1961; Williams and Creighton 2006, 54), this imagery has been adapted and assimilated into the cosmologies and the beliefs of the British Iron Age. It has therefore manifested slightly differently across each of the regional coin issue types. For example, 
with Western coinage, trees, suns, stars, and wheels are also depicted on the coins, amongst other things.

The following paper presents an analysis of these other images on coins and discusses what it infers about Iron Age cosmologies and the relative place of humans. A material culture approach highlights how the creation of coins manifests these cosmologies and in doing so, effects the way humans may have interacted with the objects. Ethnographic examples are drawn upon to help illustrate specific arguments and ideas as well as how any cosmologies identified might also be recognisable within a landscape context.

\section{Western Iron Age coins}

Uninscribed British Western coinage was struck from c. 50 BC onwards (Cottam et al. 2010, 19-20). Like most other British Iron Age coins, large quantities appear to have entered the archaeological record around the time of the Roman Conquest of Britain. Also in-keeping with general patterns in Iron Age coin deposition, the majority of Western issue coins appear to have been deposited either in hoards or in association with sacred sites, especially Romano-Celtic temples or shrines. Initially taking inspiration from Southern (Atrebatic) coinage, the Western coinage, together with other peripheral issue regions (Durotrigian/South-western and Coreltauvian/North-eastern), largely followed their own innovative developments. Although the imagery or tropes depicted on the coins have recognisable similarities with these other British Iron Age coins, the Western issue coins are visibly distinctive, and their designs demonstrate complex progressions over relatively short periods of time (see Leins 2012, 159). This makes establishing chronological developments of Western coinage difficult. Western coinage is also distinctive in its distribution, with the majority of find spots concentrated around modern-day areas of Wiltshire, Gloucestershire, North Somerset, and parts of West Oxfordshire (Fig. 1). Western coinage includes a moderate number of gold coins compared to other issuing regions although a more extensive series of silver (usually uninscribed), units also exists. Most of the gold coinage is inscribed. 
Insert Figure 1: Map of Britain showing distribution of findspots of Western issue coins (based on spatial data provided by the Portable Antiquities Scheme)

The primary distinctive characteristic of this coinage is that it has the highest proportion of human and horse associations in its imagery Table 1 (see also Pudney 2018). There are however, additional idiosyncratic combinations of images on these coins in relation to their materiality that will be explored here (see Appendix 1 for a table to $A B C$ types and key imagery). Evidence has been collated from the Portable Antiquities Scheme (PAS), which has incorporated the Celtic Coin Index. The ABC classifications (Cottam et al. 2010) are used to reference the coin types as well as to analyse them. Approximately 1690 Western coins were analysed out of over 38,000 Iron Age coins recorded to date that have a provenance within mainland Britain. The Western coinage is made up of that which has been traditionally ascribed as 'Dobunnic' but in addition, the more recently identified East Wiltshire grouping has also been included (Cottam et. al. 2010, 107-9).

Conventionally, Iron Age coins have been approached from a numismatic perspective, focusing on their cataloguing and characterisation based upon the metal types, images displayed and their possible chronological developments (de Jersey 2001; Van Arsdell 1994). Such studies have thus focused on Iron Age economics and associations with later prehistoric tribal politics. This paper aims to entrench these objects within a material culture perspective with a view to exploring the significance they may have had within Iron Age world views.

Table 1: Percentage of $A B C$ coin types per issue region with horse and human head imagery

\begin{tabular}{|l|l|l|l|}
\hline Issuer & $\begin{array}{l}\% \\
\text { ABC of } \\
\text { types } \\
\text { with } \\
\text { horse }\end{array}$ & $\begin{array}{l}\text { \% of ABC } \\
\text { types } \\
\text { with } \\
\text { head }\end{array}$ & $\begin{array}{l}\text { Total } \\
\text { number } \\
\text { of ABC } \\
\text { types }\end{array}$ \\
\hline Southern & $73 \%$ & $22 \%$ & 302 \\
\hline Kent & $56 \%$ & $36 \%$ & 120 \\
\hline $\begin{array}{l}\text { North- } \\
\text { eastern }\end{array}$ & $95 \%$ & $0 \%$ & 95 \\
\hline Western & $100 \%$ & $44 \%$ & 50 \\
\hline $\begin{array}{l}\text { South- } \\
\text { western }\end{array}$ & $30 \%$ & $0 \%$ & 26 \\
\hline $\begin{array}{l}\text { East } \\
\text { Anglian }\end{array}$ & $95 \%$ & $24 \%$ & 107 \\
\hline
\end{tabular}




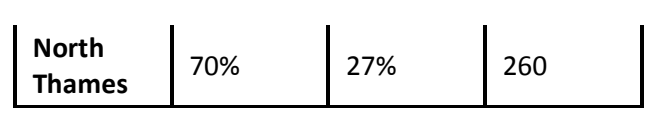

\section{Coins as affective objects}

Unlike approaches to much Iron Age material culture, especially metalwork objects (Garrow et al. 2008; Giles 2007; 2008; Hingley 1997; Joy 2009; 2011), Iron Age coins have, as aforementioned, traditionally been approached by numismatists from a functionalist perspective (e.g. Collis 1974). Often viewed as copies or imitations of continental versions (Allen 1961; 1980), they have predominately been interpreted as a primitive form of money and as valuable, but somewhat inanimate objects of power (Allen 1970; 1976; Haselgrove 1987; 1993; de Jersey 2001; Rodwell 1976; Van Arsdell 1989; 1992; 1994; Wellington 2006). Williams and Creighton (2006) however, have suggested a link between the imagery on coins and shamanic (Druidic) practice, where coins should be considered metaphors, employing the language of shamanic trance or ritual perhaps connected with a Druidic order. The power associated with such rites and the creation of coins has then also been argued as having ramifications for later Iron Age sacral kingship and the role of religious elite (Druids?) in social and political hierarchies (Creighton 2000, 22-26). Similarly, meanings behind some imagery upon Iron Age coins has been discussed in relation to Iron Age cosmologies (Aldhouse-Green 2001; 2004; Creighton 1995; Green 1992), with Iron Age coins in southeast England having been suggested as displaying mythic sun-horse imagery and associated iconography (Nash Briggs 2009). While this author does not refute Iron Age coins as powerful objects, exchanged between people for complex social and political reasons (Leins 2012), the discussion presented here builds upon the links made between coin imagery and cosmological beliefs in an attempt to better understand the types of power that may have been associated with them. The author considers the animate agency of the objects within Iron Age worlds, thus suggesting further reasons for their power and value in arenas of social and/or political exchange.

To consider the coins primarily as objects of material culture it is beneficial to set them within broader archaeological approaches to materials and objects. Material culture studies in archaeology have customarily been concerned with the animacy and agency of objects 
(Brown \& Walker 2008; Gosden 2005; Harris 2016; Knappett 2005; Knappett, \& Malafouris 2008), where agency is 'the socio-culturally mediated capacity to act' (Hoskins 2013, 74). For example, human-made objects are created intentionally. On creation the object is imbued with a certain purpose and therefore has an agency of its own (Hodder 2003). Objects are therefore made to act upon the world (Hoskins 2013). This agency can extend to things that are not created by humans, where an object gains agency in its use by a human for a specific purpose (Tilley 2001). However, it can also be argued that objects cannot have agency on their own (Knappett 2005, 29), since an object can only hold psychological presence as a result of its connection with humans, who are the actual 'primary agents'. Objects therefore cannot have true agency but when imbued by humans with a purpose, can act in a similar manner to an agent.

Following from this, assemblage theories in archaeology and approaches to object biography have led to understandings of objects as not having linear or flat ontologies (e.g. Hamilakis 2017; Harris \& Sorensen 2010; Harris 2014; Joy 2009). Instead they have powerfully affective properties or affordances (Knappett 2005, ch. 3; Norman 2012) and complex histories. Objects are thus socially powerful and have sensorial and emotional impacts on human lives (Gosden 2005). This is also echoed when considering animals and other sentient beings. Zooarchaeologists and material culture specialists focusing on British prehistory are also now approaching animals, humans and objects as cohabiting as significant others (Brittain and Overton 2013). In this sense, the social role of animals and faunal remains becomes the focus (Hambleton 2013; Madgwick 2008; 2010; Overton and Hamilakis 2013), thus viewing the faunal remains more as a form of material culture, that has meaning and cultural significance over time (Gosden and Marshall 1999; Kopytoff 1986). There is a strong argument for coins to be approached from a similar stance (Kemmers \& Nanouschka 2011). In such approaches, the creation, use, and deposition of objects can be considered to both help create, consolidate and negotiate a sense of personhood (Fowler 2005).

The status of personhood in Iron Age Britain may well have involved objects as well as other animals and beings. In animistic societies, as has been reasonably argued for Iron Age societies in Britain (Aldhouse-Green 2000; 2004; Oswald 1997), the effective power of objects and animals is central to world views. Elements of the natural and material world 
were understood as sentient; containing spirits and divine entities with which a rapport could be established. To help illustrate how such beliefs may have affected human practice, we can turn to ethnographic examples of animistic societies such as the Siberian Khanty (Jordan 2003; 2006; 2008), and the Yukaghirs (Willerslev 2007). These two specific examples demonstrate how any natural entity can be ascribed the status of a person and that every person has a spirit. For the Yukaghirs, personhood extends to all entities. In many animistic societies, such cohabitation with significant others requires those who are communicators. Shamans or shaman-like roles therefore exist, where each act as the link between significant others and the material and abstract worlds.

For the inhabitants of Iron Age Britain therefore, spirits may well have been understood to dwell in all manner of things. If coins could have powerful, affective properties, and indeed, may well have even be considered sentient or at least alive, their materiality could offer some light on the relationships between any object, animal, and human significant others therein, and perhaps also any underlying cosmologies. If each image on the coin reflects a constituent part of the coin's personhood, it would then follow that the makers of these objects would be those who were in a position to have a deeper rapport with them. Creighton (2010) argues that the imagery on some British Iron Age coins indicates that religious elite, (perhaps Druids), would have been closely involved with their creation. Thus, the coins form a significant other but the tropes on the coins (such as the horse, sun, moon, and stars) also perhaps represent additional significant others with whom Iron Age people could have a rapport. The objects may accordingly have been considered to absorb their power from the supernatural context in which they are created. The frequent deposition of coins within hoards and at sacred locations can be argued as further evidence for a link between their affectivity, cosmological beliefs and related practices.

Functions of Iron Age coins have been discussed by archaeologists and numismatists, and most agree that in many contexts they were powerful objects of metalwork that were associated with the changing nature of later Iron Age social structures, perhaps as items of elite identity and/or political propaganda (Creighton 2000; Haselgrove and Wigg-Wolf 2005; Leins 2012; Wellington 2006). The traditional approach to associate coins with specific tribal, political and/or socio-economic groups has more recently come under scrutiny. Leins $(2012,168)$ argues that similar coins and distributions do not necessarily reveal ethnic and 
socio-political unity or division. Instead, they should be interpreted as issues of emerging kings and local leaders. As such, their diversity in form and distribution reflect the fluidtity of social and political changes, as well as material traditions in the later British Iron Age. For example, coins were likely understood as part of existing, (albeit shifting), concepts of late Iron Age, high-value metalwork exchange and deposition (Joy 2016).

Metalworking in later prehistory has been argued to have been imbued with magical or supernatural qualities (Aldhouse-Green 2002; Budd \& Taylor 1995; Giles 2007; Hingley 1997). If such understandings existed in the later Iron Age, it would surely have added to the powerful effects of coins. It has been argued that those who created powerful, metal objects may have been situated in the periphery of any main social groups, perhaps being mysterious or dangerous in themselves (Budd \& Taylor 1995). If made by a religious Iron Age elite, the makers of the coins would have been those who already had the rights or access to the supernatural or to cosmological knowledge. They therefore may not have had a real need for the coins themselves but instead may have been commissioning them, or indeed may have been commissioned to make them. These people with access to powerful forces therefore facilitated their distribution, perhaps in order to enforce, remind or encourage their world view among a certain populace or group in society. In order to explore the potential affective properties of Western coins, the following analysis and discussion will focus on three main things: the significant others represented in the coins' imagery, the materiality of the coins and finally, the wider context of their production, use, and deposition.

\section{Introducing the significant others}

There are many significant others depicted on British Iron Age Western coins. Starting with the obverse imagery, the human head constitutes the most common image, with $22 A B C$ types (44\%) conforming to this trend. All types of Western silver unit contain heads on the obverse, while heads are present in only $64 \%$ of the East Wiltshire silver coins (units and half units). There are no human heads present on Western gold coinage. The head motif can be separated between those that are realistic depictions of a human head, those that are recognisable yet stylised and those that are highly abstract, but which still retain the 
essence of a human head (see Fig. 2). The stylised appearance of the head as is shown here is quite distinctive and has been described as a 'moon head' - due to the shape of the head and crescentic curls for hair (Cottam et al. 2010, 109). While 'moon heads' appear in other coinages, they are particularly common on Western coins (15 out of 25 silver types), especially those of the East Wiltshire grouping (six out of 11 silver types) and the abstract and derivative versions can be seen also to bear stylistic similarities to the moon head.

Insert Figure 2: Western coins showing typical moving horse with three tails on reverse and on obverse: Realistic head top left (ABC 2042; CCI-001559); Stylised Head 'moon head' top right (ABC 2012; PAS NMGW-OE3000); Abstract (moon)head bottom left (ABC 2021; CCI001555); Head derivative bottom right (ABC 2036; CCI-000039).

The second most common motifs on the obverse are those of a tree or branch-like image, with $10 \mathrm{ABC}$ corresponding types and the wreath (such as the versions depicted in Fig. 3). The tree image appears solely on gold staters and the wreath, either on gold staters or quarter staters. Ten types of gold coin bear the image of a wreath or wreath-type derivative, nine of which derive from the East Wiltshire group and which to date, are relatively rare. There are two types that are inscribed solely with a name on the obverse, one of which is also shown in Figure 3 but both of which are gold coins (one stater, one quarter stater), although some names are also added on the obverse or reverse of those with head designs (e.g. ABC 2042). Finally, there are those that exist with highly abstract or other designs. Some of these silver types, with a keen eye, could still be considered as relating to the human head motif (e.g. ABC 2027), while others, specifically within the East Wiltshire group, have been interpreted as depicting two opposed animals; either 'beasts' (ABC 2137 and 2140) or horses (ABC 2113 and 2116). 
Insert Figure 3: Top: Inscribed gold stater of Corio with tree on obverse (ABC 2048, CCI-SUR398AF7). Middle: Uninscribed gold stater (East Wiltshire) with wreath on obverse (ABC 2009, PAS WAW-C74642). Bottom: Inscribed gold stater of Bodvoc (ABC 2039, CCI-00433).

The reverse of the coin consistently depicts a horse. The horse is always shown as moving, never static, and either running or leaping with either two, or usually three, tails stretched out behind at almost a 90 degree angle. A range of images also usually surround the horse such as a wheel, sun, star, crescents (possibly a crescent moon), and various forms of pellets (Fig. 4). The development of the central horse and the head image, together with some of the smaller images, can be mapped back to earlier coinage appearing in southeast England and further still to continental coins (Green 1992, 157; Allen 1980; Williams and Creighton 2006 , 54). As with the Macedonian prototype for many British Iron Age cons, the copying of images such as this does not necessarily involve a similar transference of meaning.

Insert Figure 4: Glossary of some images on Western Iron Age coins (after Cottam et al. 2010, figs 138-41)

As potential animate agents, the horse, human, tree, sun, stars, crescents, wheels etc. are all brought together in production. Thus, they can be understood as significant others; partible (or permeable), fragments of the coin's personhood. The dominance of human heads and horses indicates a close relationship between humans and horses, with the imagery presenting some clear correlations. For example, the horse is almost always depicted on coins in the opposite direction to the face, possibly reflecting an empathetic or mimetic relationship between the two (Pudney 2018). Horses were bred, tamed, facilitated movement, (often including the use of wheeled vehicles), and aided in agricultural practice. The coming together of human, horse, and wheeled vehicle (and other objects) resulted in a process of enchainment (Chapman 2013). Through this enchainment selected fragments begin to link persons and places with their own life histories through their metaphorical, metonymic and mnemonic references. The frequent depositional treatment of partial and often deliberately broken horse remains and related metalwork (Pudney 2018), expands this process of fragmentation, broadening the enchained relationship to involve other aspects of the material world. 
To begin to establish the relational roles of the other images as significant others (sun, moon etc.), within broader cosmologies, closer analysis of the imagery as well as the materiality of the coins is required. Such an analysis must take into consideration the combinations of images and how they are presented on the coins (such as their appearance and relative position to other images).

\section{Celestial objects and affectivity}

Significant correlations of the material of the coins and the celestial imagery exist, indicating that cyclical movements are intentionally present and part of Iron Age cosmologies (Table 2). Links have been made between the solar horse imagery with first-century BC gold staters from south-eastern Britain and the myth of the sun-horse (Aldhouse-Green 2004; Creighton 2010; Nash Briggs 2009). The sun-horse enables the movement of the sun through the daytime sky, often being depicted carrying the sun on its back or pulling it in a wheeled vehicle, such as a chariot. At sunset, the gold disc of the sun is replaced by the either silver of the moon or bronze of the dimmed solar disc, only to return to gold again at sunrise (Nash Briggs 2009,2). A similar phenomenon is echoed in the Bronze Age Trundholm chariot, discovered in Denmark, where the horse pulls a chariot containing the sun, gold on one side and bronze on the other. Other earlier, Bronze Age objects have been discovered that also echo celestial helpers in the form of animals. An example of which can be found in Nordic Bronze Age razors where the sun and its divine 'helpers' such as the ship, the horse, the fish(whale), and the snake are closely linked to a cyclical mythology (Kaul 2005). Upon the razor, the horse is depicted as carrying the sun (or moon), across the sky, for a snake, fish, and/or a boat to then bring it back. There has been some debate as to whether evidence for an existing prehistoric, pan- northern European cosmology existed (Brück 2011) however, more recently, the sun-horse has also been argued as an interpretation of the Uffington White Horse, which was created in southern Britain during the later second or first millennium BC (Pollard 2017). 
Table 2: Predominant occurrences of coin colour and imagery on Western issue coins ${ }^{1}$ as well as cardinal direction of perspective of viewer/coin

\begin{tabular}{|c|c|c|c|c|c|c|c|c|}
\hline Colour & $\begin{array}{l}\text { Obverse } \\
\text { Image }\end{array}$ & $\begin{array}{c}\text { Dominant } \\
\text { horse } \\
\text { direction } \\
\text { on coin } \\
\text { reverse }\end{array}$ & $\begin{array}{c}\text { Time of } \\
\text { day (after } \\
\text { Nash } \\
\text { 2009) }\end{array}$ & $\begin{array}{l}\text { Celestial } \\
\text { direction } \\
\text { of rising } \\
\text { and } \\
\text { setting } \\
\text { sun/moon }\end{array}$ & $\begin{array}{c}\text { Viewer } \\
\text { perspective }\end{array}$ & $\begin{array}{l}\text { Coin } \\
\text { reverse } \\
\text { face } \\
\text { perspective }\end{array}$ & Images above horse & $\begin{array}{c}\text { Images } \\
\text { below } \\
\text { horse }\end{array}$ \\
\hline $\begin{array}{l}\text { Silver I } \\
\text { moon }\end{array}$ & $\begin{array}{l}\text { Human } \\
\text { head / } \\
\text { moonhead }\end{array}$ & $\mathrm{R}-\mathrm{L}$ & Night & $\begin{array}{l}\text { East } \\
\text { West }\end{array}$ & $\mathrm{N}$ & $S$ & $\begin{array}{l}\text { Bird's head } \\
\text { Crescent \& winged } \\
\text { pellet in ring } \\
\text { Cross \& winged } \\
\text { pellet } \\
\text { Crescent \& ringed } \\
\text { pellet }\end{array}$ & $\begin{array}{c}\text { Flower } \\
\text { motif } \\
/ \\
\text { wheel }^{2}\end{array}$ \\
\hline $\begin{array}{l}\text { Gold / } \\
\text { sun }\end{array}$ & $\begin{array}{l}\text { Tree (axis } \\
\text { mundi) }\end{array}$ & L-R & Day & $\begin{array}{l}\text { East } \\
\text { West }\end{array}$ & $S$ & $\mathrm{~N}$ & $\begin{array}{l}\text { Charioteer's arm } \\
\text { Crescent \& rings \& } \\
\text { crosses } \\
\text { Crescent \& ringed } \\
\text { pellets } \\
\text { Name } \\
\text { Sun wheels - } \\
\text { (Cogwheel sun; } \\
\text { Solar spiral; Sun } \\
\text { ring) }\end{array}$ & Wheel \\
\hline
\end{tabular}

If we associate the gold colour of coins with the sun and silver with the moon, additional cosmological relationships can be explored. However, it must be noted that interpretive issues exist with some of the images. For example, occurrence of a wheel image is positioned below the horse on $90 \%$ of gold Western coin types. The wheel imagery could reflect the presence of a wheeled vehicle, such as a chariot although the often-varied appearance of the wheel has also been suggested to reflect a 'solar wheel', with its different permutations replicating the diurnal journey of the sun across the sky (Cottam et al. 2010, 107). If a solar wheel, it would perhaps be expected that it was positioned above the horse, in the sky, especially on a 'sun-coin' or gold coin. Instead, on gold coinage, it is usually positioned below the horse (in 20 types), sometimes with other sun-related imagery above (e.g. solar spirals, sun ring etc.), perhaps making it more likely that in these cases, the wheel is indeed related to a wheeled vehicle, possibly a chariot. The only coins where a wheel is

\footnotetext{
${ }^{1}$ For a full table of images per type of coin, see Appendix 1

${ }^{2}$ The wheel below the horse on silver coinage only occurs in the East Wiltshire units
} 
obviously present on the reverse of silver 'moon-coins' occur within the East Wiltshire group. Of these 11 silver types, eight have wheels (or cog wheels) present on the reverse, three of which are situated below the horse $(A B C 2119 ; 2128 ; 2131)$ and four are positioned above the horse ( $A B C 2119 ; 2122 ; 2125 ; 2134)$. Otherwise, no Western silver coins tend to contain obvious wheel images. In order to further examine this relationship, the gold coinage will be focused on followed by the silver.

\section{'Sun coins' and 'Moon coins'}

On gold 'sun-coinage' where day is being reflected and where the wheel is usually situated beneath the horse we find a permeable link between the wheel and the sun - both of which (appear to) rotate and therefore facilitate different types of cyclical transformation (as inferred in the Trundholm Chariot). With the wheel beneath the horse, either one or a series of crescent shapes usually sits above the animal, as in Figure 5 (see also ABC 2003; 2039; 2066; 2069). The crescent can be argued to represent the moon, which on a 'suncoin' would not need to be considered out of place in the daytime sky if feasibly mimicking the crescent moon often witnessed during the daylight hours. Thus we have gold coins, perhaps embodying the sun, with the wheel beneath and often a crescent shape (moon?) above. The presence of each celestial object becomes marked in the combination of imagery and material.

This is similar with the silver coins, where perhaps the silver takes on the effects of the moon. Although the wheel is not present on most silver coinage and even in the silver units where a wheel is present, a circular image is also apparent, such as a 'sunburst' or pellet-inring, and can be situated either above or below the horse (e.g. ABC 2042, 2122) (see also Fig. 5). This circle imagery has been largely interpreted as a solar trope (see Fig. 4) however, it could feasibly represent a bright, full moon. The importance of the moon in 'Celtic' societies is attested in the Coligny calendar, a lunisolar calendar that focuses on the lunar month as well as the solar year (Lehoux 2007, 483) and for which the calendrical system likely long predates its probable second century AD date (Olmstead 1992). The calendar indicates a deep knowledge of the cosmos and how the cycles of the moon's phases and solar movements can be measured. The sunburst(?) or full moon often reflected above the horse on silver coins perhaps informs the viewer of the complex 
relationships between each celestial object at any given time. These relationships would have been in a state of constant flux, as days, nights, seasons, and years passed. The objects may therefore present a snapshot of this highly fluid, relational state which in turn, could reflect the time of the day, month, or year in which the coins were produced, or perhaps record specific events, thus chronicling certain histories or mythologies.

Insert Figure 5: Above: Inscribed gold stater with wheel beneath horse (ABC 2066; CCI011989). Below: Silver unit with wheel above horse (ABC 2122; CCI-981052)

The reflection of lunar and solar movements as presented in the Western coin imagery therefore inherently links to the passing of time. Depicted central to this is the image of the horse. Nash Briggs $(2009,2)$ notes that in sun-horse mythologies the horse always travels clockwise. Where the sun-horse travels by night, the horse is usually depicted moving from right to left across the face of the coin. Equally, when travelling by day, the left-right movement is observed. Thus, on the gold (sun)coins we have day-time reflected by the direction of the horse and on the silver, (moon cons), night-time is represented (see table 2).

However, further analysis of the direction of movement of the horse and association of day and night with sun and moon respectively, raises potential inconsistencies or errors. For example, the sun rises in the east and moves westwards until it sets. It then must somehow move from west back to east during the night for it to rise once more in the morning from the east. For the horse's movement to reflect the day time (as on the sun coins), it would consequently need to be depicted as moving from the right of the coin (east), to the left of the coin (west). Instead, the opposite is apparent, and the horse's direction directly contradicts that of the direction of movement of the sun. That is, unless it demands that the coin is viewed from a specific cardinal perspective.

To clarify, if the horse is depicted moving from left to right and for it to reflect day (i.e. the horse's movements follow that of the rising and setting sun), then I (the viewer) must be looking south, following the sun's arc through the sky from left (east) to right (west) (see Fig. 6). Similarly, for the horse's movements from right to left to mimic the movement of the 
moon in the night's sky, an E-W movement ${ }^{3}$ would correlate with a right-left depiction and he perspective of the viewer dictated as facing north. This presents an inverted perspective to that for gold coins. The images on the gold coin therefore assumes that the viewer's perspective is different to that for a silver coin (Table 2), and essentially equates the cardinal point north with night and the south with day.

Insert Figure 6: Schematic diagram showing association of day and night in relation to the direction of horse, cardinal points and therefore also the perspective the coin would be viewed from.

This enforced perspective additionally acts on another level: In order for the perspective of the viewer to change, that of the coin must also. If we consider that a gold and silver coin are linked, that they embody night and day, then in a general sense, the reverse of the object itself faces in a different direction during the day as it does at night (see Table 2); the reverse 'face' of the silver coins are directed south and the reverse of the gold coins face north, thus meaning that the obverse of each coin faces in the opposite cardinal direction (obverse gold/south and obverse silver/north), but that also of the (human)viewer. This correlation of imagery and direction would not only have affected the agency of the object (Ingold 2007), but fundamentally formed an affective statement: The aspect of the coin dictates the perspective and perception of the human viewer. The coin could even therefore be considered to harnesses the essence of day and night and of sun and moon and as a result, it transforms to coincide with celestial changes. Further analysis could be done to address this correlation on other regional coinages and, where there may be exceptions to this rule, how they might reflect the effective and affective properties of the coins.

The animate enchainment of celestial, human, and horse others is therefore both relational and contextual. Their varied appearance reflects the different elements of each coin according to the relative balance of significant parts. The depiction of the horse in motion additionally echoes its dynamism that in turn rotates the chariot wheel, sun, and moon. In

\footnotetext{
${ }^{3}$ Here the net movement of east to west remains despite the eastward movement of the moon amongst the stars each night.
} 
order for such cosmologies to be transposed into the material realm through the production of coins, those people designing and producing the dies must indeed have required an intimate knowledge of the cosmos and the relative place of humans, horses, and celestial objects therein. This perhaps strengthens the argument that spiritual leaders (possibly Druids), were heavily involved in their design and creation (Creighton 2010) and that the objects literally took on some of the supernatural powers of their constituent parts.

\section{Tethering the abstract: The production, use, and deposition of Western coins}

We have seen the association of the cardinal points in relation to movement of the sun and the moon as well as the aspect from which coins were seemingly meant to be viewed. In many animist societies, cosmologies associated with cardinal points are also often transposed onto other elements of daily human life. For example, in cosmologies of the Siberian Khanty east is associated with birth and life while west is linked to the end of life and death. Similarly, south is equated to the upper world, where the sun is strongest and resides for more time and north, with the darker, lower world (Jordan 2003). In their assessment of shamanic practices and beliefs in Iron Age society, Williams and Creighton $(2006,49)$, highlight the common presence of a central axis mundi, or pillar, connecting the upper, middle, and lower worlds of the cosmos. This is a common concept in many animistic societies. For the Siberian Khanty the River $\mathrm{Ob}$ acts as the connecting force (Jordan 2000). The concept of the axis mundi thus exists in the abstract realm but also translates on to a physical plane, associating the upper world of the cosmos, with a middle or material world wherein the cardinal points of something like a river can bind places together and act as the connecting force. Downstram is associated with the underworld with death and disease - while upstream is clean and associated as flowing towards the upper, predominantly spirit world. Daily activities are therefore conducted accordingly. For example, burials must take place downstream from settlements so as to ensure bad spirits or essences do not flow up the river and pollute the settlement.

Evidence from the Iron Age in Britain for alliances between daily activity and cardinal points has been debated in studies that focus on the orientation of roundhouses as well as the zoning of activities (Parker-Pearson 1996; Pope 2007; Woodward and Hughes 2007). While 
Pope (2007) identifies many factors likely contributed to the orientation of roundhouses as well as the organisation of space therein, cosmological beliefs cannot be completely ruled out. After all, cosmologies are likely inherently linked with the pragmatic elements of the environment people inhabit and experience. Such experiences help to form understandings of times of day, year, and any associated cosmologies and mythologies therein, could not only dictate certain routines or taboos for daily activity and domestic architecture but could also have significant repercussions for the production or birth of metal objects within human worlds and in relation to the sun, moon and stars. Although abstract sets of Iron Age knowledge surrounding the significance of cardinal points are potentially unknowable, the thing connecting these more abstract associations, can be explored through analyses of both spatial and temporal patterns of specific activities and occurrences. Here, evidence for the location of coin production will be considered within the wider landscape context and in relation to imagery displayed uniquely on the Western coins themselves (the tree or branch image). The possible oppidum at Bagendon and the broadly contemporaneous hillfort at Ditches will be considered according to their landscape context and evidential role in the production of Western coins. The general depositional patterns of Western coins will also be considered, together with certain hoarding events.

Distribution densities of Western coins suggest a centre of gravity very close to present-day Cirencester and Bagendon (Bevan 2012, 501; Leins 2012, 49). While coin moulds have been found at several locations across the Western coin issue region and therefore a single production site is unlikely, the distribution densities and the recovery of pellet moulds at the site (Clifford 1961; Trow 1988; Trow et al. 2009), infer that Bagendon and environs likely served as a political and social core of later Iron Age regional society. Both Bagendon and Ditches are situated at either end of a watercourse, the Bagendon Brook. While the siting of major Iron Age settlements close to water sources is perhaps not unusual or unsurprising, other landscape features and the management of the landscape suggest that there was more to their siting than purely readily available water and access to good riverine transport routes. Situated at the confluence of the Bagendon Brook and the River Churn (Fig. 7), Bagendon is a polyfocal complex (oppida?), that includes a large c. $1^{\text {st }}$ century AD enclosure and linear dyke system that may have been linked to the corralling of horses (Moore 2012). Together, the dyke system and Bagendon acted as a portal through which people, material 
goods, and ideas moved. The manipulation of the landscape in the creation of the dykes meant that they literally straddled the mouth of the valley, funnelling the river water.

Insert Figure 7: Map to show landscape context of Bagendon and Ditches hillfort (after Trow 1988, 20)

Established during the first century BC Ditches hillfort is sited c. $3 \mathrm{~km}$ north of the oppidum, overlooking the head of the valley. This earlier site thus controlled the source of the watercourse (Trow 1988; Trow et al. 2009, 45). Both sites were therefore liminal, sitting between worlds at opposite ends of the river. At the same time, both sites are central in the production of metalwork (coins). The river may therefore have corresponded to a physical axis mundi, allowing movement through the physical world and facilitating the creation and flow of Western coinage.

Wider settlement patterns indicate that social and political networks were changing during the late, pre-Roman Iron Age, and that the development of Bagendon corresponds with the emergence of new power (Moore 2007; Trow et al. 2009). The production of coins also appears to be linked directly to shifting power bases in eastern England where continental connections help support the rise of new social groups over the religious classes (Creighton 2000). Coins are therefore central in the negotiation of new or shifting power just as this renegotiation of the human place within the cosmos becomes materialised in the landscape. Considering the associations and axis mundi, Bagendon (the later site), is situated further south but also down-stream of Ditches, towards the point where the Bagendon Brook meets the River Churn. The geographic shift in the 'central place' along the axis mundi may reflect the changing place or perspective of humans in relation to cosmos; perhaps where Bagendon serves as a portal to new or expanding/additional worlds.

The alternative perspective on Western coins as presented here could therefore provide a different understanding of how material objects were bound up both within regional vicissitudes in Western Britain and broader social and political change during the later Iron Age. Leins' (2012) work on the spatial distributions of British Iron Age coins demonstrates that gold coins had a role in the mediation of long distance, less frequent relationships or 
social/political links. Silver coins however, appear to have been used in more localised and frequent interactions. But, within this, there exists clear differences depending on the type of coin, the issuer, and the imagery. For example, certain types of Western coins are widely circulated but less conspicuous in fairly isolated areas such as ABC 2024 and 2027 in NE of the region (Leins 2012, 161-2). This demonstrates often very different depositional patterns and circulation. Coin function in some contexts means that they are used as items of exchange, to assist in the formation and negotiation of social and political bonds. For example, gold Western coinages appear to be predominately utilised in contexts where high intrinsic value is also required such as areas in SE Wales, where high-value metalwork exchange remains less affected by coin-use. In other areas, where silver issues were more common may have been more acceptable for use in exchanges due to the more developed tradition of coin-use in such a given area (Leins 2012,169). The convergence of specific silver coin types such as ABC 2015, 2018 and ABC 2012 around the Bagendon (and Cirencester) areas is therefore significant. If indeed coins are being exchanged as a means of regularly maintaining and negotiating economic, social, or political networks this indicates that Bagendon and the surrounding area is an important locale for such action. These sites were therefore central in the production of supernatural and transformative metalwork (coins), but also within the local and wider landscape as focal points for social and economic networks.

Since silver coinages were predominately circulated within closer-distance networks and between communities familiar with coin-use, then the associations of night and the affordances of the silver coin warrant consideration. While silver has less intrinsic value and therefore perhaps more suitable to certain types of exchange, around c. $74 \%$ of recorded Western coins are silver. If these coins are generally exchanged with people within close socio-economic circles or in more everyday transactions, these viewers of the coins would potentially be required to know what perspective they are viewing the object from in order for the directional motifs to correlate with real celestial movements. Through repeated acts of exchange in which silver coins are circulated, handled and viewed from a specific perspective it enforces this sense of 'knowing' and therefore inclusivity. As argued by Harris and Sorensen (2010), the affective field in which the coins are produced and exchanged are 'sticky with emotion' and thus help to foster a sense of community. 
As objects central to negotiation of high-level or longer distance social relationships, the imagery on Western issue gold coins could be equally significant. As previously argued, the coins have certain affordances; the imagery dictates a certain human perspective and thus affects interaction with the object. Additional to the celestial imagery, Western gold coins are associated with a unique image. Instead of a human head on the obverse, they contain the iconic Western (or Dobunnic emblem); the tree or branch image (Fig. 5). The image is found on the obverse of c. $42 \%$ of $A B C$ Western coin types but if we remove those of the East Wiltshire group from this, c. $77 \%$ of gold $A B C$ types contain the tree image on the obverse. It also only appears on gold staters, the largest and most intrinsically valuable type of Iron Age coin and not on quarter staters. The tree image tends to have ten branches, five down each side of a main trunk. At the top and base of the trunk there is usually a round pellet or pellet within a circle. There are also usually pellets depicted upon each branch.

The tree in Iron Age expression has been argued to be associated with the yew tree (Aldhouse-Green 2000; Allen 1958), an ancient, long-living tree with slow-growing, evergreen properties. Such 'tree-of-life' characteristics are supported by its argued significance in later Iron Age religion; its poisonous qualities linking it with death (AldhouseGreen 2010), and mother goddess associations as representative of fertility (AldhouseGreen 2000; Bevan-Jones 2016). Another suggestion is the ash tree (Rudd 2003). Either interpretation links the tree to a 'tree-of-life' concept, and which may have acted as an axis mundi on the coins, connecting layers of the universe, uniting the sky (branches), earth (trunk) and underworld (roots) and therefore perhaps becoming somewhat totemic of any political group or collective identity which may have existed, 'Dobunnic' or other.

The embodiment of the horse, the possible axis mundi (or totem), day-time and gold within these particular objects would make a statement to the people involved in any transaction. Joy (2009) has argued that the motifs on Iron Age mirrors would have been immediately recognisable to those who encountered them, acting as a material metaphor. The inscribed motifs on the objects refer to and gather up different elements of a series of types of object forms from the later Iron Age and in doing so, potential meaning and significance were inscribed into the artefact. People could then relate to the object on multiple levels through the familiar cultural motifs. Equally, the imagery and materiality of the gold coinage would provide their receivers with a clear account of the cosmologies of those who created (and 
perhaps also offered), the coins. These cosmologies would potentially be reassuring and could help to (re)affirm bonds and allegiances but similarly, could have a very different effect; perhaps stating difference. This difference would surely have been articulated in the tree image. Even regarding the latter however, the exchange of gold as high intrinsic value could have been reassuring if received within a broader and deeper set of existing and wellunderstood metalwork exchange traditions. It would also act to enchain the receiver within this 'other' while perhaps invoking familiar or known mythologies or cosmologies through the images on the reverse, therefore helping to increase or nurture bonds of protection or allegiance.

Western coins are also commonly interred into the ground in acts of intentional deposition. As already mentioned, Western coinage, like much British Iron Age coinage, is often found deposited at sacred or religious sites (Briggs et al. 1992; Haselgrove1989; Haselgrove \& Wigg-Wolf 2005), many of which are known for the existence of a later Romano-Celtic temple at the same locations. For example, considerable deposits of Western coinage have been found at Bath, Henley Wood (Watts and Leach 1996), Sapperton (Moore 2001), Nettleton (Wedlake 1982), Uley (Woodward and Leach 1993) and Wycomb (Timby 1998), indicating that a link between metalwork deposition (especially coins) and cosmologies continues into the post-conquest period. The depositional locations of coins at emergent Romano-British religious sites further adds to the argument for their pre-existing religious and/or cosmological significance during the Iron Age. Iron Age coin deposition can therefore help us identify sites of spiritual significance during the later Iron Age where contemporary structures may not exist. For example, Somerford Keynes Neigh Bridge, Gloucestershire, appears to have been a site of spiritual significance at a crossing of the River Thames, but which does not appear to be directly associated with a later RomanoCeltic temple or shrine (Miles et al. 2007; Morton 1997; Thomas \& Collard 2000). Of the thirteen British Iron Age coins recovered, twelve are Western issues and as with many Iron Age coins, may have entered the archaeological record in the post-conquest period (King 2005). The relatively high, post-conquest occurrence of Iron Age coin deposition should then be set within the context of the Roman conquest and related changes; where an increased need to re-enforce a sense of (an Iron Age) (sacred) place may have been a reality, or perhaps where Iron Age cosmologies were literally put to death and buried. 
Western coinage has also been found within a number of Iron Age and conquest period hoards, although they are perhaps less common than other issue regions. Some 346 Iron Age coin hoards are known from Britain (de Jersey 2014) yet only 14 are known to contain mostly, if not exclusively, Western issue coins. They are all found either within or at the edge of the main area of Western coin distribution. Four contain only gold coins, five silver (not including Urchfont III as a single, separate hoard), and four contain a mix of coin types (See Appendix 2). Approximately c. 93\% of coins from Western hoards are silver coins and only seven percent gold, making the proportion of silver coins found within hoards compared with gold coins considerably different to the general picture (c. $74 \%$ silver). Although, the substantial quantity of silver coins from the Pershore Hoards (Hurst \& Leins 2013), likely affects this data.

Many of the hoards are small, containing less than 10 silver units with the exception of the Pershore Hoards (I and II), in Worcestershire, Nunney, and Farmborough, both in Somerset. Most of the hoards are deposited in the period AD 10 - 40, (de Jersey's 'Phase 8'), contrasting to the general pattern in which de Jersey's Phase $6(50-20 \mathrm{BC})$, has produced the highest number (de Jersey 2014, 12). While the chronological pattern of Western coin hoards (between c. $50 B C$ and $A D$ 45), perhaps correlates with the chronology of Western coin production and the general pattern does not demonstrate any stark differences to other coin-issuing regions, one hoard certainly stands out from other Western hoards; The Farmborough Hoard.

In the case of the Farmborough hoard in North Somerset, the act of deposition brings together a large quantity of inscribed Western coins. Of the 61 gold staters included in the hoard, all are Western issues of ABC 2048; gold staters inscribed CORIO (de Jersey 2014, 346) and which depict the tree on the obverse (Fig. 3). On the reverse, the central horse is depicted from left to right, with crescent and CORIO above the horse and a wheel below, with various other pellets around the edges. This particular coin type has been deliberately collected for deposition in this context then placed within a hollow flint. Flint does not occur within the immediate vicinity and therefore it would have been brought c. $25+\mathrm{km}$ in order for it to be included in this particular deposition. As a Phase 7 hoard (c. $20 \mathrm{BC}-\mathrm{AD}$ $10)$, it is somewhat of an obscurity since nearly all Phase 7 hoards are either dominated by coins attributed to the Southwestern regional coinage and therefore found in the region, or 
otherwise those of the South or North Thames regions. It is perhaps significant that the siting of this hoard so close to a possible 'Dobunnic' territorial boundary (de Jersey 2001; Van Arsdell 1994) was at a time when neighbouring societies to the southwest also appear to be actively, and relatively frequently hoarding coins. Curteis (2006) identifies that many Iron Age coins recovered across the South Midlands were deliberately chosen for deposition based upon their imagery and metallurgy. Coins were also deposited in highly meaningful locations such as in entrance ways or in association with ritual practices such as sacrifice and feasting (Curteis 2006; Leins 2007).

The deliberate choice of coin imagery and liminal location for the Farmborough Hoard may have served as a transformative performance. Assuming that CORIO relates to a specific person, this transformative act could feasibly be similarly associated, perhaps as a means of consolidating territorial zones. The deliberate inclusion of CORIO coins thus equates to socio-political leadership but additionally, the presence of the tree or axis mundi on the coins may have been required in order to ensure they tethered the different layers of the cosmos and CORIO with the coins' ultimate depositional location, thus (re)enforcing or underpinning the boundary. The coins were thus targeted as explicit objects of late Iron Age power. They were directly linked to key significant others within structures of socio-political and/or supernatural authority and, by depositing them in the ground, this power was being enchained with place with the help of the axis mundi.

\section{Conclusion}

British Iron Age Western coinage was designed and created with intent. These were powerful objects not just because they were of intrinsic worth or because they were signs of dominance created by social, political and/or religious elite. Instead, these were hugely powerful objects because they embodied knowledge of the cosmos and the relative place of humans. The coins brought together celestial objects, animals, humans and in the case of the majority of gold staters, the tree or potential axis mundi. The images presented indicate a sun-horse assisting the sun through the sky on its diurnal journey, perhaps also ensuring the moon's safe passage in its stead. Coins therefore enchained different significant others and presented a materialisation of the cosmos and associated mythologies. Gold coins reflect the sun in their materiality and are feasibly associated with daytime and the cardinal 
direction South. Silver coins can be seen to reflect the moon, night time and North. The imagery on the coins was designed to enforce a particular viewpoint when looking at it. The direction of the horse, the positioning of the wheel, sun, moon etc. meant that the viewer would have to alter their perspective if the images were to 'make sense'; facing north for silver coins or south for gold.

The relative position of celestial and terrestrial things would therefore have been a material metaphor, familiar to those who shared the same myths and understanding. In turn this would surely have affected the way in which people responded to these objects and the knowledge of the cosmos pictured upon them. Assuming that people were aware where the sun rose and set they would have immediately been included within this cosmological dialogue. Similarly, those who did not know (or notice), may have been excluded from it. Even then however, in receiving one of these objects the recipient becomes enchained not only with the giver of the coin, but the significant others (sun, moon, stars, horses and humans etc.) that constitute the object. In the case of the gold coinage, one of its primary uses may have been to forge new relationships or maintain distant or less familiar ones, as also suggested by depositional patterns (Leins 2012). Perhaps by giving these objects to others, the people(s) often ascribed as Dobunni, were in fact, sharing part of their world. The circulation of silver coinage indicates closer, more frequent exchanges where the sharing of night-time (and perhaps more mysterious?) celestial events and occurrences helped to consolidate the existing community.

The cosmologies reflected upon these coins can also be seen echoed in the wider landscape of coin creation and deposition at the heart of the Western issue region as well as at its limits. The presence of an axis mundi on gold staters and the relationship between Bagendon and Ditches hillfort in the creation of Western coins indicates that concepts of a layered universe may have been transposed into multiple aspects of the material world. The deposition of coins at sacred sites and in hoards thus not only forms part of a wellestablished, later prehistoric tradition of metalwork deposition but enforces the role of cosmologies in ritual practice. The deliberate collection of CORIO coins in the Farmborough hoard emphasises the role of coinage as cosmological objects in the negotiation and strengthening of socio-political landscapes during the later Iron Age. The design, production, use and deposition of British Iron Age Western coinage was bound up with 
cosmological knowledge. As a result, these were powerful, affective objects which enabled the dynamic materialisation of sacred power within later Iron Age socio-political structures.

Caroline Pudney, Department of History and Archaeology, University of Chester, Parkgate Road, Chester, CH1 4BJ. (c.pudney@chester.ac.uk).

\section{Acknowledgements}

Thanks must go to the Portable Antiquities Scheme for providing full access to the data and for use of specific coin images under the CC BY attribution licence. A big thank you to the editor and anonymous reviewers whose comments were hugely constructive and have made for a stronger article. The support of colleagues, especially Howard Williams and Ruth Nugent has been of great value. As always, any oversights or inaccuracies remain the author's own.

\section{Bibliography}

Agapitov, N. N. and Khangalov, M. 1883. Materials for the Study of Shamanism in Siberia.

Aldhouse-Green, M. J. 2000. Seeing the wood for the trees: the symbolism of trees and wood in Ancient Gaul and Britain. Canolfan Uwchefrydiau Cymreig a Cheltaidd Prifysgol Cymru

Aldhouse-Green, M. J. 2001. Cosmovision and metaphor: monsters and shamans in GalloBritish cult-expression. European Journal of Archaeology 4(2), pp. 203-32.

Aldhouse-Green, M. J. 2004. An Archaeology of Images. Iconology and cosmology in Iron Age and Roman Europe. London: Routledge

Aldhouse-Green, M. J. 2006. Metaphors, meaning and money: contextualizing some symbols on Iron Age coins. In Celtic coinage: new discoveries, new discussion, ed. P. de Jersey. Oxford BAR International Series, 29-40.

Aldhouse-Green, M. J. 2010. Caesar's druids: story of an ancient priesthood. Yale University Press.

Allen, D. F. 1958. Belgic coins as illustrations of life in the late pre-Roman Iron Age of Britain. Proceedings of the Prehistoric Society 24, 43-63. 
Allen, D. F. 1961. A study of Dobunnic coinage. In Bagendon: a Belgic oppidum, ed. E. M. Clifford Cambridge: Heffer

Allen, D. 1970. The coins of the Iceni. Britannia 1, 1-33.

Allen, D. F. 1976. Wealth, coinage and money in Celtic society. In To illustrate the monuments. Essays on archaeology presented to Stuart Piggott on the occasion of his sixtyfifth birthday, ed. J.V.S. Megaw. London: Thames \& Hudson. 200-08

Allen, D. F. 1980. The Coins of the Ancient Celts. Edinburgh: Edinburgh University Press.

Bevan, A. 2012. Spatial methods for analysing large-scale artefact inventories. Antiquity 86, 492-506.

Bevan-Jones, R. 2017. The Ancient Yew: a history of Taxus baccata. Third edition. Oxford: Oxbow Books.

Briggs, D., Haselgrove, C., and King, C. E. 1992. The Iron Age and Roman coins from Hayling Island temple. British Numismatic Journal 62, 1-62.

Brittain, M. and Overton, N. J. 2013. The Significance of Others: A Prehistory of Rhythm and Interspecies Participation. Society and Animals 21, 134-49.

Brown, L. A., \& Walker, W. H. 2008. Prologue: archaeology, animism and non-human agents. Journal of Archaeological Method and Theory, 15(4), 297-99.

Brück, J. 2011. Fire, Earth, Water. In The Oxford Handbook of the Archaeology of Ritual and Religion, ed. T. Insoll Oxford: OUP, 387 - 404.

Budd, P. and Taylor, T. 1995. The faerie smith meets the bronze industry: magic versus science in the interpretation of prehistoric metal-making. World Archaeology 27, 133-43.

Chapman, J. 2013. Fragmentation in archaeology: People, places and broken objects in the prehistory of South Eastern Europe. Routledge: London.

Clifford, E. M. 1961. Bagendon: a Belgic oppidum. Cambridge: Heffer

Collis, J. R. 1974. A Functionalist Approach to pre-Roman Coinage. In Coins and the Archaeologist, eds. P.J. Casey, and R. Reece, Numismatic Fine Arts Council, 1-11.

Cottam, E., de Jersey, P., Rudd, C., and Sills, J. 2010. Ancient British Coins. Aylsham: Chris Rudd.

Creighton, J. 1995. Visions of power: imagery and symbols in Late Iron Age Britain. Britannia 26, 285-301.

Creighton, J. 2000. Coins and Power in Late Iron Age Britain. Cambridge: Cambridge University Press. 
Curteis, M. 2006. Distribution and ritual deposition of Iron Age coins in the South Midlands. In Celtic Coinage: New Discoveries, New Discussion, ed. P. de Jersey. Oxford: BAR International Series, 61-79.

Davies, E. 1809. The Mythology and Rites of the British Druids. London: J. Booth.

Dowson, T. and Porr, M. 2001. Special objects - special creatures. Shamanistic imagery and the Aurignacian of South-West Germany. In The Archaeology of Shamanism, ed. N. Price. London: Routledge, 163-77.

Fitzpatrick, A. P. 1989. Celtic (Iron Age) religion - traditional and timeless. Scottish Archaeological Review 8, 123-29.

Fowler, C. 2005. The Archaeology of Personhood. An anthropological approach. London: Routledge.

Garrow, D., Gosden, C. \& Hill, J. D. (eds.). 2008: Rethinking Celtic Art. Oxford: Oxbow Books.

Giles, M. 2007. Making Metal and Forging Relations: Ironworking in the British Iron Age. Oxford Journal of Archaeology 26(4), 395-413.

Giles, M. 2008: Seeing red: the aesthetics of martial objects the British and Irish Iron Age. In Rethinking Celtic Art, eds. D. Garrow, C. Gosden, \& J. D. Hill. Oxford: Oxbow Books, 59-77.

Gosden, C. 2005. What Do Objects Want? Journal of Archaeological Method and Theory 12 (3): 193-211.

Gosden, C., and Marshall, Y 1999. The cultural biography of objects. World Archaeology 31(2), 169-78.

Green, M. J. 1992. The iconography of Celtic coins. In Celtic Coinage: Britain and Beyond. The Eleventh Oxford symposium on coinage and monetary history, ed. M. Mays. BAR British Series 222. Oxford: BAR, 151-64.

Guttmann, E. B. A. 2005. Midden cultivation in prehistoric Britain: arable crops in gardens. World Archaeology, 37(2), 224-39.

Harries, J. 2016. A stone that feels right in the hand: Tactile memory, the abduction of agency and presence of the past. Journal of Material Culture 22: 1, 110-30.

Harris, O. J. 2014. (Re)assembling Communities. Journal of Archaeological Method and Theory, 21(1), 76-97.

Harris, O. J. T., \& Sørensen, T. F. 2010. Rethinking emotion and material culture. Archaeological Dialogues, 17(2), 145-163. 
Hambleton, E. 2013. The Life of Things Long Dead: a Biography of Iron Age Animal Skulls from Battlesbury Bowl, Wilthsire. Cambridge Archaeological Journal 23(3), 477-94.

Hamilakis, Y. (2017). Sensorial assemblages: affect, memory and temporality in assemblage thinking. Cambridge Archaeological Journal, 27(1), 169-182.

Haselgrove, C. 1987. Iron Age coinage in south-east England: the archaeological context. BAR British Series 174. Oxford: BAR.

Haselgrove, C. 1989. Iron Age coin deposition at Harlow Temple, Essex. Oxford Journal of Archaeology 8, 73-88.

Haselgrove, C. 1993. The Development of British Iron Age Coinage. The Numismatic Chronicle 153, 31-63.

Haselgrove, C. and Wigg-Wolf, D. eds. 2005. Iron Age Coinage and Ritual Practices. Mainz: Verlag Philipp von Zabern.

Hingley, R. 1997. Iron, Ironworking and Regeneration: a study of the symbolic meaning of metalworking in Iron Age Britain. In Reconstructing Iron Age Societies, eds. A. Gwilt and C. Haselgrove. Oxford: Oxbow, 9-15.

Hodder, I 2003. The "social" in Archaeological Theory: An Historical and Contemporary Perspective. In A Companion to Social Archaeology, eds. L. Meskell and R. Pruecel. Malden MA: Blackwell, 23-42

Hoskins, J 2013. Agency, biography and objects. In Handbook of Material Culture, eds. C. Tilley, W. Keane \& S. Kuechler-Fogden. London: Sage, 74-84.

Hurst, D., \& Leins, I. 2013. The Pershore hoards and votive deposition in the Iron Age. Proceedings of the Prehistoric Society 79, 297-325

Hutton, R. 2001. Shamans: Siberian Spirituality and the Western Imagination. London: Hambledon.

Ingold, T. 2007. Materials against materiality. Archaeological Dialogues, 14, 1-16.

de Jersey, P. 2001. Celtic Coinage in Britain. Princes Risborough: Shire Publications Ltd

Jones, M. 1981. The Development of Crop Husbandry', In The Environment of Man: The Iron Age to the Anglo-Saxon Period, eds. M. Jones and G. Dimbleby. Oxford: British Archaeological Reports (British Series) 87, 95-127.

Jordan, P. 2003. Material Culture and Sacred Landscape. The anthropology of the Siberian Khanty. Walnut Creek: AltaMira Press.

Jordan, P. 2006. Analogy. In Mesolithic Britain and Ireland. New Approaches, eds. C. Cornellier and G. Warren. Stroud: Tempus, 83-100. 
Jordan, P. 2008. Northern landscape, northern mind: on the trail of an archaeology of hunter-gatherer belief. In Belief in the Past. Theoretical Approaches to the Archaeology of Religion, eds. D. S. Whitley and K. Hays-Gilpin. Walnut Creek, CA: Left Coast Press, 227-246.

Joy, J. 2009. Reinvigorating object biography: reproducing the drama of object lives. World Archaeology, 41:4, 540-556

Joy, J. 2011. 'Fancy objects' in the British Iron Age: why decorate? Proceedings of the Prehistoric Society 77, 205-229.

Joy, J. 2016. Hoards as collections: re-examining the Snettisham Iron Age hoards from the perspective of collecting practice. World Archaeology, 48(2), 239-253.

Kaul, F. 2005. Bronze Age tripartite cosmologies. Prähstorische Zeitschrift. 80: 2, 135-48

Kemmers, F. and Nanouschka, M. 2011. Rethinking numismatics. The archaeology of coins. Archaeological Dialogues 18(1), 87-108.

King, C. 2005. The coins from Somerford Keynes, Neigh Bridge. Oxford Archaeology Draft Report.

http://thehumanjourney.net/html pages/microsites/cotswoldweb/text/sknbcoins.pdf Date Accessed 14/12/2015.

Knappett, K. 2005. Thinking Through Material Culture. An Interdisciplinary Perspective. Philadelphia: University of Pennsylvania Press.

Knappett, C., \& Malafouris, L. (eds.). 2008. Material agency: towards a non-anthropocentric approach. New York: Springer.

Kopytoff, I. 1986. The cultural biography of things: commoditization as a process, In The Social Life of Things: Commodities in Cultural Perspective, ed. A. Appadurai. Cambridge: Cambridge University Press, 64-91.

Lehoux, D. 2007. Astronomy, Weather, and Calendars in the Ancient World. Parapegmata and Related Texts in Classical and Near-Eastern Societies. Cambridge: Cambridge University Press.

Leins, I. 2007. Coins in context: coinage and votive deposition in Iron Age South-East Leicestershire. British Numismatic Journal 77, 22-48.

Leins, I. 2012. Numismatic data reconsidered: coin distributions and interpretation in studies of late Iron Age Britain. Unpublished Ph.D. Thesis. Newcastle University

Madgwick, R. 2008. Patterns in the modification of animal and human bones in Iron Age Wessex: revisiting the excarnation debate, In Changing Perspectives on the First Millennium BC: Proceedings of the Iron Age Research Student Seminar 2006, eds. O. P. Davies, N. Sharples and K. E. Waddington. Oxford: Oxbow, 99-118.

Madgwick. R. 2010. Bone modification and the conceptual relationship between humans and animals in Iron Age Wessex, In Integrating Social and Environmental Archaeologies: 
Reconsidering Deposition, eds. J. Morris and M. Maltby. British Archaeological Reports International Series 2077, Oxford: Archaeopress, 66-82.

Miles, D., Palmer, S., Perpetua Jones, G., and Smith, A., 2007. Iron Age and Roman settlement in the Upper Thames Valley: excavations at Claydon Pike and other sites within the Cotswold Water Park. Thames Valley Landscapes 26, Oxford Archaeology.

Moore, T. 2001. Hailey Wood Camp: a Roman Temple complex in the Cotswolds? Transactions of the Bristol and Gloucestershire Archaeological Society 119, 83-93.

Moore, T. 2007. Life on the edge? Exchange, settlement and identity in the later Iron Age of the Severn Cotswolds. In, The Later Iron Age in Britain and Beyond, eds. C. Haselgrove and T. Moore. Oxford: Oxbow, 41-61.

Moore, T. 2012. Beyond the Oppida: Polyfocal Complexes and Late Iron Age Societies in Southern Britain. Oxford Journal of Archaeology 31(4), 391-417.

Morton, R., 1997. Lower Mill Farm, Somerford Keynes, Gloucestershire: Archaeological Assessment (CAT Report: 97510). Cirencester: Cotswold Archaeology.

Nash Briggs, D. 2009. Reading the images on Iron Age coins: 2. Horses of the day and night. Chris Rudd List 106: 2-4. Available at: http://www.celticcoins.com/wpcontent/uploads/2014/12/The-sun-horse.pdf (accessed 6 December 2016).

Norman, D. 2013. The design of everyday things: Revised and expanded edition. New York: Basic Books

Olmsted, G. S. 1992. The Gaulish calendar: A reconstruction from the bronze fragments from Coligny, with an analysis of its function as a highly accurate lunar-solar predictor, as well as an explanation of its terminology and development. Bonn: R. Habelt.

Oswald, A. 1997. A Doorway on the Past: Practical and Mystic Concerns in the Orientation of Roundhouse Doorways. In Reconstructing Iron Age Societies, eds. A. Gwilt and C. Haselgrove. Oxbow: Oxford, pp 87-95

Overton, N. J. and Hamilakis, Y. 2013. A manifesto for a social zooarchaeology. Swans and other beings in the Mesolithic. Archaeological Dialogues 20(2), 111-36.

Parker-Pearson, M. 1996. Food, fertility and front doors in the first millennium BC. In The Iron Age in Britain and Ireland: Recent Trends, eds. T.C. Champion and J.R. Collis. Sheffiled: J.R. Collis Publications, pp 117-32.

Pollard, J. 2017. The Uffington White Horse geoglyph as sun-horse. Antiquity, 91(356), 40620.

Pope, R. 2007. Ritual and the roundhouse. A critique of recent ideas on the use of domestic space in later British prehistory. In The earlier Iron Age in Britain and the near Continent, eds. C. Haselgrove and R. Pope. Oxford: Oxbow Books, 204-28. 
Pudney, C. 2018. Socio-semiotics and the symbiosis of humans, horses, and objects in later Iron Age Britain, Archaeological Journal, DOI: 10.1080/00665983.2018.1441105

Rodwell, W. J. 1976. Coinage, oppida and the rise of Belgic power in South Eastern Britain. In Oppida: the beginnings of urbanisation in barbarian Europe, eds. B. Cunliffe and R. Rowley. BAR Special Series 11. Oxford: British Archaeological Reports, 184-367.

Rudd, C. 2003. Ash and Dobunnic Tree. Chris Rudd List 72, November 2003. http://www.celticcoins.com/wp-content/uploads/2015/01/list72.pdf $\quad$ (Accessed 03/03/2017)

Thomas, A. and Collard, M., 2000. Lower Mill Farm, Somerford Keynes, Gloucestershire. Archaeological Evaluation (Report No. 001240). Cirencester: Cotswold Archaeology.

Tilley, C. 2001. Ethnography and Material Culture. In. Handbook of Ethnography, eds. P. Atkinson, A. Coffey, S. Delamont, J. Lofland and L. Lofland. London: Sage, 258-72.

Timby, J. 1998. Excavations at Kingscote and Wycomb, Gloucestershire. Cirencester: Cotswold Archaeological Trust.

Trow, S. D. 1988. Excavations at Ditches hillfort, North Cerney, Gloucestershire, 1982-3. Transactions of the Bristol and Gloucestershire Archaeological Society 106, 19-85.

Trow, S.D., James, S. and Moore, T. 2009. Becoming Roman, Being Gallic, Staying British: Research and Excavations at Ditches 'hillfort' and villa 1984-2006. Oxford: Oxbow.

Van Arsdell, R. D. 1989. Celtic Coinage of Britain. London: Spink.

Van Arsdell, R. D. 1992. Money, supply and credit in Iron Age Britain. In Celtic Coinage: Britain and Beyond, ed. M. Mays. The Eleventh Oxford symposium on coinage and monetary history. BAR British Series 222. Oxford: BAR, 139-50.

Van Arsdell, R. D. 1994. The Coinage of the Dobunni. Money Supply and Coin Circulation in Dobunnic Territory. Oxford: Oxford University Committee for Archaeology.

Van Arsdell, R. D. 2015. Semiotics of Celtic Coins X-Inventions, Replicas and Applying the Brakes. Date Accessed: 07/09/2017

Wait, G. 1985. Religion and Ritual in Iron Age Britain (Parts 1 and 2). BAR British Series 149. Oxford: British Archaeological Reports.

Watts, L., and Leach, P. 1996. Henley Wood, Temples and Cemetery. Excavations 1962 1969 by the late Ernest Green and others. CBA Research Report 99. York: Council for British Archaeology.

Wedlake, W. 1982. The excavations of the shrine of Apollo at Nettleton, Wiltshire, 19561971. Report of the Research Committee of the Society of Antiquaries of London 40. London. 
Wellington, I. 2006: The role of Iron Age coinage in archaeological contexts. In Celtic coinage: new discoveries, new discussion, ed. P. de Jersey. Oxford BAR International Series, 81-96.

Willserslev, R. 2007. Soul Hunters: Hunting, Animism, and Personhood among the Siberian Yukaghirs. Berkeley: University of California Press.

Williams, M. 2003. Growing metaphors: The agricultural cycle as metaphor in the later prehistoric period of Britain and North-western Europe. Journal of Social Archaeology, 3(2), 223-55.

Williams, M. and Creighton, J. 2006. Shamanic practices and trance imagery in the Iron Age. In Celtic Coinage: New Discoveries, New Discussion, ed. P. de Jersey. Oxford: BAR International Series, 49-59.

Woodward, A. and Hughes, G. 2007. Deposits and doorways: patterns within the Iron Age settlement at Crick Covert Farm, Northamptonshire. In: The Earlier Iron Age in Britain and the Near Continent, eds. C. Haselgrove and R. Pope. Oxford: Oxbow, pp. 185-203.

Woodward, A. and Leach, E. 1993. The Uley Shrines. Excavation of a ritual complex on West Hill, Uley, Gloucestershire: 1977-9. London: English Heritage

Author Information: Caroline is Lecturer in Archaeology at the University of Chester and specialises in Iron Age and Roman archaeology, material culture studies, and public archaeology, with a particular interest in the archaeology of Wales and the borders. The genesis of the research presented here can be found in her Doctoral thesis (Cardiff University), which focused on the Iron Age-Roman transition in the Severn Estuary region from a material culture perspective. Previously, Caroline worked as Community Archaeologist for Cadw, the Welsh Government's Historic Environment Service, as well as in the commercial sector. 
Appendix 1: Western Iron Age Coins (ABC type and key imagery)

\begin{tabular}{|c|c|c|c|c|c|c|c|}
\hline \multirow{2}{*}{$\begin{array}{l}\text { 'Tribal' } \\
\text { Group }\end{array}$} & \multirow[t]{2}{*}{$A B C$} & \multirow[t]{2}{*}{ Metal } & \multirow[t]{2}{*}{ Denom. } & \multirow[t]{2}{*}{ Obverse } & \multicolumn{3}{|c|}{ Reverse } \\
\hline & & & & & $\begin{array}{c}\text { Horse } \\
\text { direction }\end{array}$ & Above horse & Below horse \\
\hline Dobunni & 2003 & Gold & Stater & Tree & L-R & charioteer arm & wheel \\
\hline Dobunni & 2006 & Gold & Stater & Tree & L-R & Crescent \& Ring & wheel \\
\hline Dobunni & 2009 & Gold & $\begin{array}{l}\text { Qtr } \\
\text { Stater }\end{array}$ & Wreath & L-R & Cog sun wheel & Animal \\
\hline Dobunni & 2012 & Silver & unit & Moonhead & $\mathrm{R}-\mathrm{L}$ & Bird head \& Wheel & Cock \\
\hline Dobunni & 2015 & Silver & unit & Moonhead & $\mathrm{R}-\mathrm{L}$ & Bird head & Flower \\
\hline Dobunni & 2018 & Silver & unit & Moonhead & $\mathrm{R}-\mathrm{L}$ & Bird head & Flower \\
\hline Dobunni & 2021 & Silver & unit & Moonhead & $\mathrm{R}-\mathrm{L}$ & Bird head & Flower \\
\hline Dobunni & 2024 & Silver & unit & Moonhead & $\mathrm{R}-\mathrm{L}$ & $\begin{array}{l}\text { Crescent \& Winged pellet in } \\
\text { ring }\end{array}$ & Flower \\
\hline Dobunni & 2027 & Silver & unit & Moonhead & $\mathrm{R}-\mathrm{L}$ & Cross \& Winged pellet in ring & Flower and pellet in ring \\
\hline Dobunni & 2030 & Silver & unit & Moonhead & $\mathrm{R}-\mathrm{L}$ & Winged pellet in ring & Flower \\
\hline Dobunni & 2033 & Silver & unit & Moonhead & $\mathrm{R}-\mathrm{L}$ & Ring inside 4 pellets & Cross \\
\hline Dobunni & 2036 & Silver & unit & Moonhead & L-R & $\begin{array}{l}\text { Cruciform pattern of ring and } \\
\text { crescents }\end{array}$ & Cross \\
\hline Dobunni & 2039 & Gold & Stater & BODVOC & L-R & $\begin{array}{l}\text { Crescent and } 2 \text { ringed-pellets } \\
\text { (Hidden face) }\end{array}$ & wheel \\
\hline Dobunni & 2042 & Silver & unit & Head \& BODVOC & L-R & pellets \& rings & Sun ring \\
\hline Dobunni & 2045 & Silver & unit & Head \& BODVOC & L-R & pellets \& rings & Sun ring \\
\hline Dobunni & 2048 & Gold & Stater & Tree & L-R & CORIO \& crescent & wheel \\
\hline Dobunni & 2051 & Gold & $\begin{array}{l}\text { Qtr } \\
\text { Stater }\end{array}$ & COR & L-R & Sun ring & Animal \\
\hline Dobunni & 2054 & Gold & Stater & Tree & L-R & COMUX \& crescent & wheel \\
\hline Dobunni & 2057 & Gold & Stater & Tree & L-R & $\begin{array}{l}\text { CATTI \& crescent; cross; } \\
\text { pellets }\end{array}$ & wheel \\
\hline Dobunni & 2060 & Gold & Stater & Tree & L-R & IMAMN \& crescent; cross & wheel \\
\hline Dobunni & 2063 & Silver & unit & Abstract Head & $\begin{array}{l}\text { R-L; } \\
\text { (INAMN } \\
\text { around } \\
\text { horse) }\end{array}$ & ringed pellets & ringed pellets \\
\hline Dobunni & 2066 & Gold & Stater & Tree & L-R & $\begin{array}{l}\text { ANTED \& crescent; cross; } \\
\text { RIGV. }\end{array}$ & wheel \\
\hline Dobunni & 2069 & Gold & Stater & Tree & L-R & $\begin{array}{l}\text { ANTED \& crescent; cross; } \\
\text { beaded ring }\end{array}$ & wheel \\
\hline Dobunni & 2072 & Silver & unit & Abstract Head & $\mathrm{R}-\mathrm{L}$ & TED/TEO \& cross & ringed pellet; AN \\
\hline Dobunni & 2075 & Gold & Stater & Tree & L-R & EISV \& crescent; pellets & wheel \\
\hline Dobunni & 2078 & Gold & Stater & Tree & L-R & $\begin{array}{l}\text { EISV \& cross; pellets (hidden } \\
\text { face) }\end{array}$ & wheel \\
\hline Dobunni & 2081 & Silver & unit & Abstract Head & $\mathrm{R}-\mathrm{L}$ & El \& pellet & pellet \& SV \\
\hline Dobunni & 2084 & Silver & unit & Abstract Head & $\mathrm{R}-\mathrm{L}$ & El \& pellet & SV \\
\hline $\begin{array}{l}\text { East } \\
\text { Wilts. }\end{array}$ & 2089 & Gold & Stater & Wreath & $L-R$ & Solar spiral & wheel \\
\hline $\begin{array}{l}\text { East } \\
\text { Wilts. }\end{array}$ & 2091 & Gold & Stater & Plain & L-R & Solar spiral & wheel \\
\hline $\begin{array}{l}\text { East } \\
\text { Wilts. }\end{array}$ & 2093 & Gold & $\begin{array}{l}\text { Qtr } \\
\text { Stater }\end{array}$ & Wreath & $L-R$ & Wheel & wheel \\
\hline $\begin{array}{l}\text { East } \\
\text { Wilts. }\end{array}$ & 2095 & Gold & $\begin{array}{l}\text { Qtr } \\
\text { Stater }\end{array}$ & Wreath & $\mathrm{R}-\mathrm{L}$ & Wheel & wheel \\
\hline $\begin{array}{l}\text { East } \\
\text { Wilts. }\end{array}$ & 2097 & Gold & $\begin{array}{l}\text { Qtr } \\
\text { Stater }\end{array}$ & Wreath & $L-R$ & Wheel & wheel \\
\hline $\begin{array}{l}\text { East } \\
\text { Wilts. }\end{array}$ & 2099 & Gold & $\begin{array}{l}\text { Qtr } \\
\text { Stater }\end{array}$ & Wreath & L-R & charioteer arm & wheel \\
\hline
\end{tabular}




\begin{tabular}{|c|c|c|c|c|c|c|c|}
\hline $\begin{array}{l}\text { East } \\
\text { Wilts. }\end{array}$ & 2101 & Gold & $\begin{array}{l}\text { Qtr } \\
\text { Stater }\end{array}$ & Wreath & L-R & Solar spiral & wheel \\
\hline $\begin{array}{l}\text { East } \\
\text { Wilts. }\end{array}$ & 2103 & Gold & $\begin{array}{l}\text { Qtr } \\
\text { Stater }\end{array}$ & Wreath & $\mathrm{R}-\mathrm{L}$ & Wheel $\& 2$ rings & wheel \& ring \\
\hline $\begin{array}{l}\text { East } \\
\text { Wilts. }\end{array}$ & 2105 & Gold & $\begin{array}{l}\text { Qtr } \\
\text { Stater }\end{array}$ & Wreath & $\mathrm{R}-\mathrm{L}$ & Cog sun wheel & Cog sun wheel \\
\hline $\begin{array}{l}\text { East } \\
\text { Wilts. }\end{array}$ & 2107 & Gold & $\begin{array}{l}\text { Qtr } \\
\text { Stater }\end{array}$ & $\begin{array}{l}\text { Cruciform } \\
\text { wreath }\end{array}$ & $\mathrm{R}-\mathrm{L}$ & Ringed pellet; rings & Ringed pellet; rings \\
\hline $\begin{array}{l}\text { East } \\
\text { Wilts. }\end{array}$ & 2019 & Gold & $\begin{array}{l}\text { Qtr } \\
\text { Stater }\end{array}$ & Wreaths & $\mathrm{R}-\mathrm{L}$ & Floral sun & Cogwheel \\
\hline $\begin{array}{l}\text { East } \\
\text { Wilts. }\end{array}$ & 2113 & Silver & unit & Opposed horses & $\mathrm{R}-\mathrm{L}$ & & Cock head; ringed pellet \\
\hline $\begin{array}{l}\text { East } \\
\text { Wilts. }\end{array}$ & 2116 & Silver & unit & Opposed horses & $\mathrm{R}-\mathrm{L}$ & Small horse (upside down) & Boar \\
\hline $\begin{array}{l}\text { East } \\
\text { Wilts. }\end{array}$ & 2117 & Silver & unit & Stylised head & $\mathrm{R}-\mathrm{L}$ & Lyre & Cogwheel \\
\hline $\begin{array}{l}\text { East } \\
\text { Wilts. }\end{array}$ & 2119 & Silver & unit & Moonhead & $\mathrm{R}-\mathrm{L}$ & Wheel & Wheel \\
\hline $\begin{array}{l}\text { East } \\
\text { Wilts. }\end{array}$ & 2122 & Silver & unit & Moonhead & $\mathrm{R}-\mathrm{L}$ & Wheel & Ringed pellet \\
\hline $\begin{array}{l}\text { East } \\
\text { Wilts. }\end{array}$ & 2125 & Silver & unit & Moonhead & R-L & Wheel & Ring; ringed pellet \\
\hline $\begin{array}{l}\text { East } \\
\text { Wilts. }\end{array}$ & 2128 & Silver & unit & Moonhead & $\mathrm{R}-\mathrm{L}$ & 2 large pellets & Wheel; ring \\
\hline $\begin{array}{l}\text { East } \\
\text { Wilts. }\end{array}$ & 2131 & Silver & unit & Moonhead & $\mathrm{R}-\mathrm{L}$ & Ring & Wheel \\
\hline $\begin{array}{l}\text { East } \\
\text { Wilts. }\end{array}$ & 2134 & Silver & unit & $\begin{array}{l}\text { Abstract } \\
\text { Moonhead }\end{array}$ & $\mathrm{R}-\mathrm{L}$ & Wheel (beaded rim) & Ring; ringed star \\
\hline $\begin{array}{l}\text { East } \\
\text { Wilts. }\end{array}$ & 2137 & Silver & $\begin{array}{l}\text { Half } \\
\text { unit }\end{array}$ & Opposed beasts & $\mathrm{R}-\mathrm{L}$ & Sun ring & ringed pellet \\
\hline $\begin{array}{l}\text { East } \\
\text { Wilts. }\end{array}$ & 2140 & Silver & $\begin{array}{l}\text { Half } \\
\text { unit }\end{array}$ & Opposed beasts & $R-L$ & Cog sun wheel & $\begin{array}{l}\text { ringed pellet; rings; } \\
\text { pellets }\end{array}$ \\
\hline
\end{tabular}




\section{Appendix 2: Western Coin Hoards (from de Jersey 2014)}

\begin{tabular}{|c|c|c|c|c|c|c|c|c|c|}
\hline $\begin{array}{l}\text { Hoard } \\
\text { No. (de } \\
\text { Jersey } \\
\text { 2014) } \\
\end{array}$ & Hoard Name & Phase & Plated & Qty & Silver & Qty & Gold & Qty & Notes \\
\hline 72 & Kings Stanley & 8 & & & & & 2057 & 1 & \\
\hline 72 & Kings Stanley & 8 & & & & & 2066 & 1 & \\
\hline 73 & Sherborne & 8 & & & & & 2057 & 1 & \\
\hline 73 & Sherborne & 8 & & & & & 2066 & 7 & \\
\hline 73 & Sherborne & 8 & & & & & 2078 & 1 & \\
\hline 118 & Bewdley & 8 & & & & & 2075 & 3 & \\
\hline 118 & Bewdley & 8 & & & & & 1854 & 1 & \\
\hline 119 & Leominster/Broomyard & 7 & & & 2036 & 2 & & & $\begin{array}{c}\text { only } 2 \\
\text { recorded out } \\
\text { of possible 6- } \\
8 \\
\end{array}$ \\
\hline 120.1 & Pershore I & 8 & & & & & DT 100 & 1 & \multirow{14}{*}{$\begin{array}{l}\text { Pershore } \\
\text { hoards only } \\
\text { include coins } \\
\text { definitely } \\
\text { part of } \\
\text { hoards }\end{array}$} \\
\hline 120.1 & Pershore I & 8 & & & & & 1743 & 1 & \\
\hline 120.1 & Pershore I & 8 & & & & & 2006 & 2 & \\
\hline 120.1 & Pershore I & 8 & & & & & 2780 & 1 & \\
\hline 120.1 & Pershore I & 8 & & & & & 2039 & 1 & \\
\hline 120.1 & Pershore I & 8 & & & & & 2057 & 1 & \\
\hline 120.1 & Pershore I & 8 & & & 1836 & 1 & & & \\
\hline 120.1 & Pershore I & 8 & & & 2015 & 1 & & & \\
\hline 120.1 & Pershore I & 8 & & & 2018 & 4 & & & \\
\hline 120.1 & Pershore I & 8 & & & 2021 & 3 & & & \\
\hline 120.1 & Pershore I & 8 & & & 2036 & 917 & & & \\
\hline 120.1 & Pershore I & 8 & & & Frags. & 6 & & & \\
\hline 120.1 & Pershore I & 8 & 2036 & 43 & & & & & \\
\hline 120.1 & Pershore I & 8 & $2012-2027$ & 1 & & & & & \\
\hline 120.2 & Pershore II & 8 & & 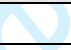 & & & 488 & 1 & \\
\hline 120.2 & Pershore II & 8 & & . & & & 2003 & 1 & \\
\hline 120.2 & Pershore II & 8 & & 8 & 20 & & 2006 & 1 & \\
\hline 120.2 & Pershore II & 8 & & & $8=$ & & 2048 & 1 & \\
\hline 120.2 & Pershore II & 8 & & & 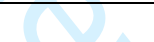 & & 2039 & 1 & \\
\hline 120.2 & Pershore II & 8 & & & 2015 & 13 & & & \\
\hline 120.2 & Pershore II & 8 & & & $2015 / 2018$ & 73 & & & \\
\hline 120.2 & Pershore II & 8 & & & 2018 & 12 & & & \\
\hline 120.2 & Pershore II & 8 & & & $2018 / 2022$ & 20 & & & \\
\hline 120.2 & Pershore II & 8 & & & 2021 & 23 & & & \\
\hline 120.2 & Pershore II & 8 & & & 2018-2021 & 29 & & & \\
\hline 120.2 & Pershore II & 8 & & & 2072 & 1 & & & \\
\hline 120.2 & Pershore II & 8 & & & 2081 & 1 & & & \\
\hline 120.2 & Pershore II & 8 & & & 2036 & 64 & & & \\
\hline 120.2 & Pershore II & 8 & & & 2042 & 1 & & & \\
\hline 120.2 & Pershore II & 8 & & & uncertain & 41 & & & \\
\hline 120.2 & Pershore II & 8 & $2015 / 2018 / 2021$ & 4 & & & & & \\
\hline 120.2 & Pershore II & 8 & 2036 & 1 & & & & & \\
\hline 120.2 & Pershore II & 8 & uncertain & 6 & & & & & \\
\hline 220 & Farmborough & 7 & & & & & 2048 & 61 & $\begin{array}{c}\text { Hollow flint } \\
\text { container }\end{array}$ \\
\hline 221 & Nunney & 9 & & & 2015 & 5 & & & \\
\hline 221 & Nunney & 9 & & & 2018 & 4 & & & pottery \\
\hline 221 & Nunney & 9 & & & 2021 & 3 & & & container \\
\hline 221 & Nunney & 9 & & & 2024 & 13 & & & \\
\hline
\end{tabular}




\begin{tabular}{|c|c|c|c|c|c|c|c|}
\hline 221 & Nunney & 9 & 2027 & 26 & & & \\
\hline 221 & Nunney & 9 & & & 2057 & 1 & \\
\hline 221 & Nunney & 9 & & & 2066 & 4 & \\
\hline 221 & Nunney & 9 & 2072 & 15 & & & \\
\hline 221 & Nunney & 9 & 2081 & 10 & & & \\
\hline 221 & Nunney & 9 & 2084 & 2 & & & \\
\hline 274 & Calne Without & 6 & 2015 & 1 & & & \\
\hline 274 & Calne Without & 6 & 2021 & 1 & & & \\
\hline 275 & Chirton & 6 & 2128 & 5 & & & \\
\hline 275 & Chirton & 6 & 2131 & 1 & & & \\
\hline 284 & Savernake & 9 & & & 2091 & 14 & \\
\hline 284 & Savernake & 9 & 1346 & 9 & & & \\
\hline 284 & Savernake & 9 & 1376 & 1 & & & \\
\hline 284 & Savernake & 9 & Tiberius & 1 & & & \\
\hline 288 & Urchfont I & 6 & 2125 & 1 & & & \\
\hline 288 & Urchfont I & 6 & 2128 & 1 & & & \\
\hline 288 & Urchfont I & 6 & 2131 & 1 & & & \\
\hline 289 & Urchfont II & 6 & 2128 & 9 & & & \\
\hline 289 & Urchfont II & 6 & 2131 & 7 & & & \\
\hline 290 & Urchfont III & 6 & 2128 & 1 & & & Possibly from \\
\hline 290 & Urchfont III & 6 & 2131 & 1 & & & $\begin{array}{c}\text { same deposits } \\
\text { as other } \\
\text { Urchfont } \\
\text { hoards }\end{array}$ \\
\hline
\end{tabular}




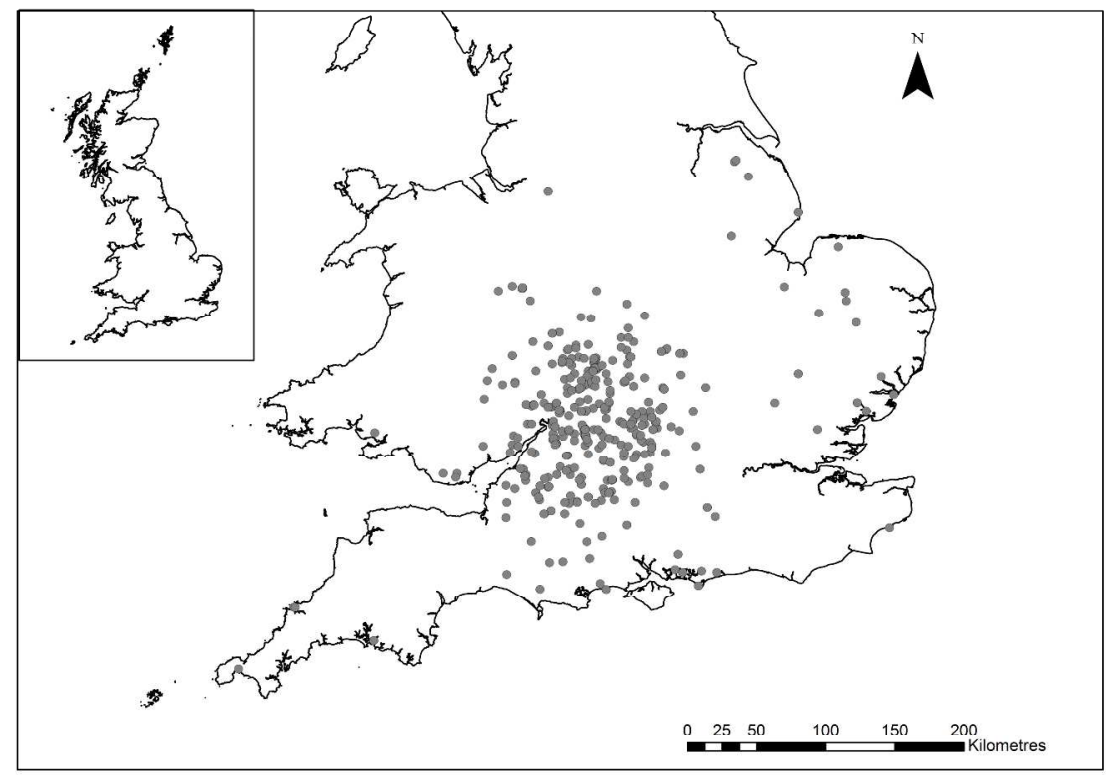

Map of Britain showing distribution of findspots of Western issue coins (based on spatial data provided by the Portable Antiquities Scheme)

$304 \times 228 \mathrm{~mm}(300 \times 300$ DPI $)$ 

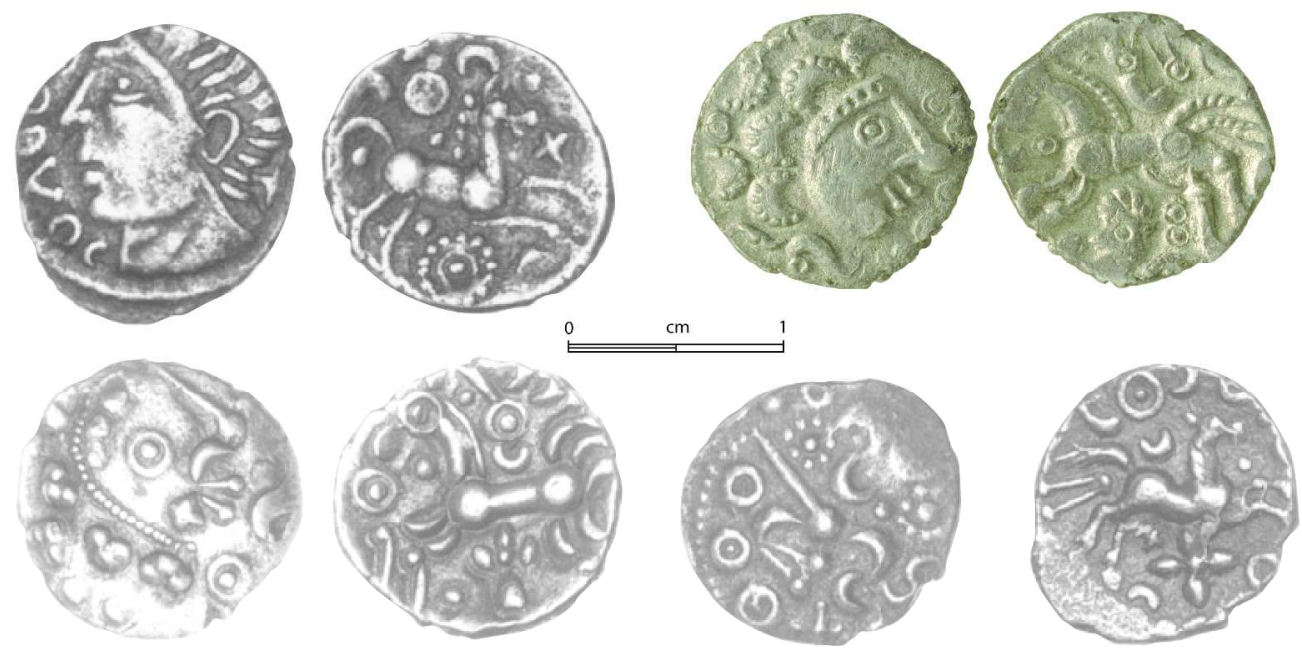

Western coins showing typical moving horse with three tails on reverse and on obverse: Realistic head top left (ABC 2042; CCI-001559); Stylised Head 'moon head' top right (ABC 2012; PAS NMGW-0E3000); Abstract (moon)head bottom left (ABC 2021; CCI-001555); Head derivative bottom right (ABC 2036; CCI000039).

$292 \times 145 \mathrm{~mm}(300 \times 300 \mathrm{DPI})$ 

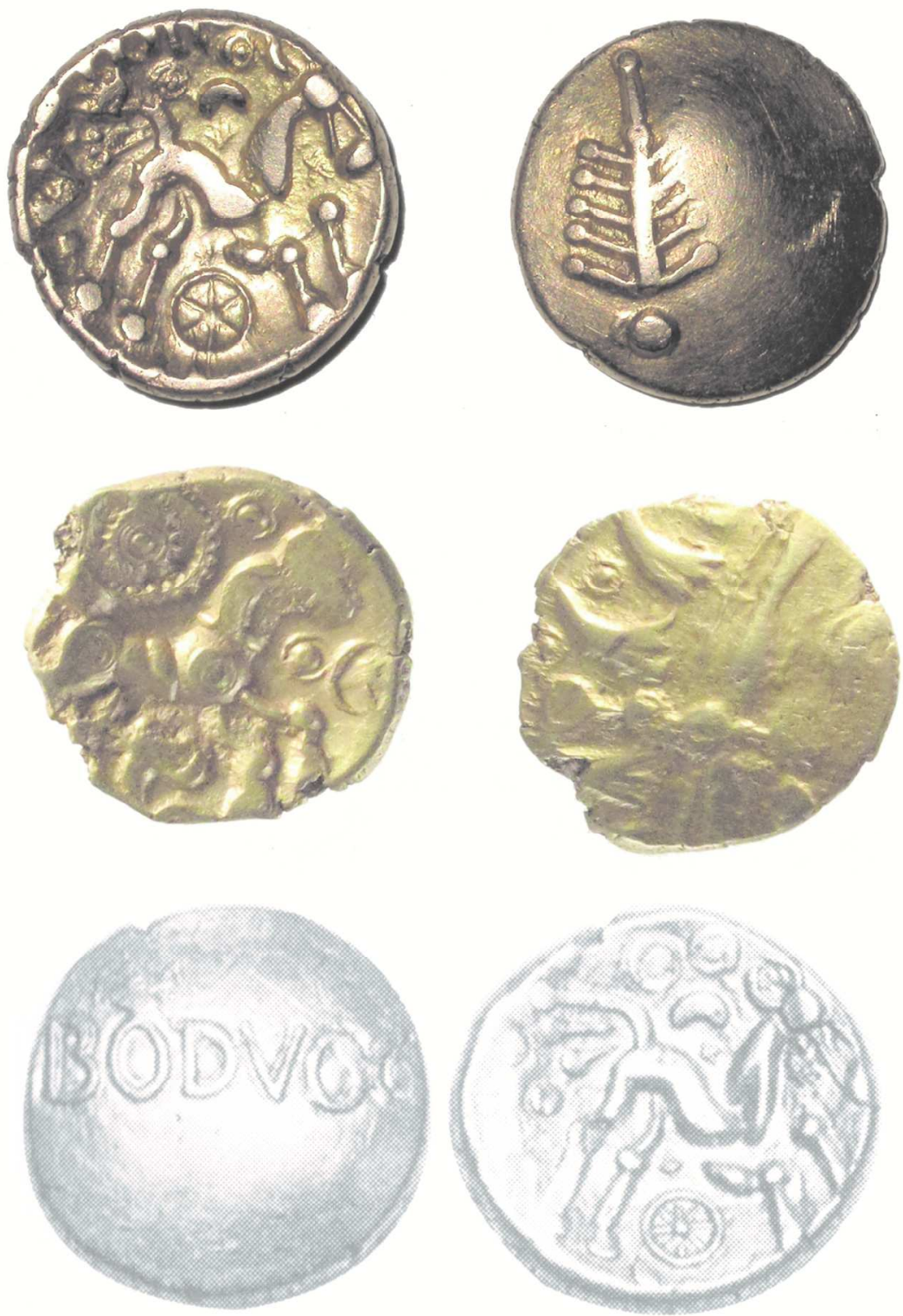

Top: Inscribed gold stater of Corio with tree on obverse (ABC 2048, CCI-SUR-398AF7). Middle: Uninscribed gold stater (East Wiltshire) with wreath on obverse (ABC 2009, PAS WAW-C74642). Bottom: Inscribed gold stater of Bodvoc (ABC 2039, CCI-00433).

$126 \times 162 \mathrm{~mm}(300 \times 300$ DPI $)$ 


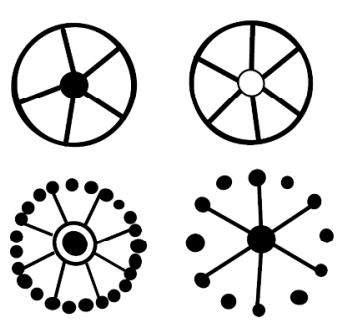

Sun wheels

- Pellet

Pellet in ring

(- Large pellet in ring

$\underset{+}{x}$ Crosses
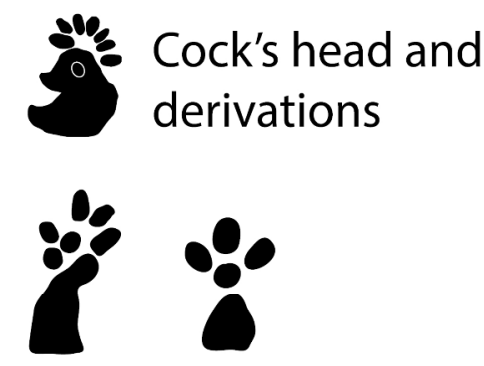

คـ Flower

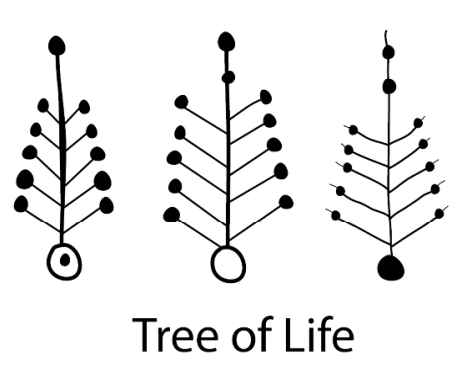

$\because$ Pelletal sun rings<smiles>[Si]#[Zn]</smiles>
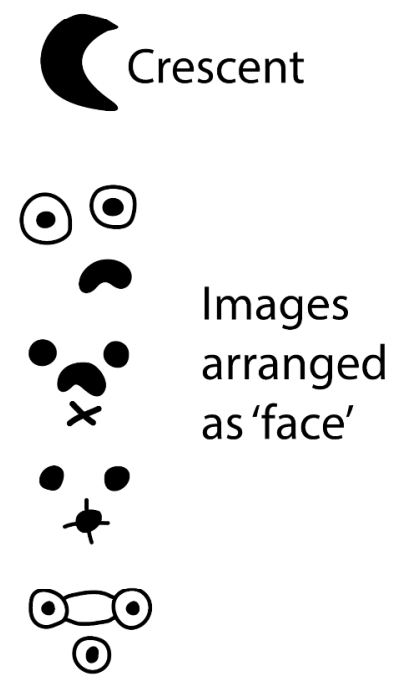

Glossary of some images on Western Iron Age coins (after Cottam et al. 2010, figs 138-41) $204 \times 272 \mathrm{~mm}(300 \times 300$ DPI $)$ 

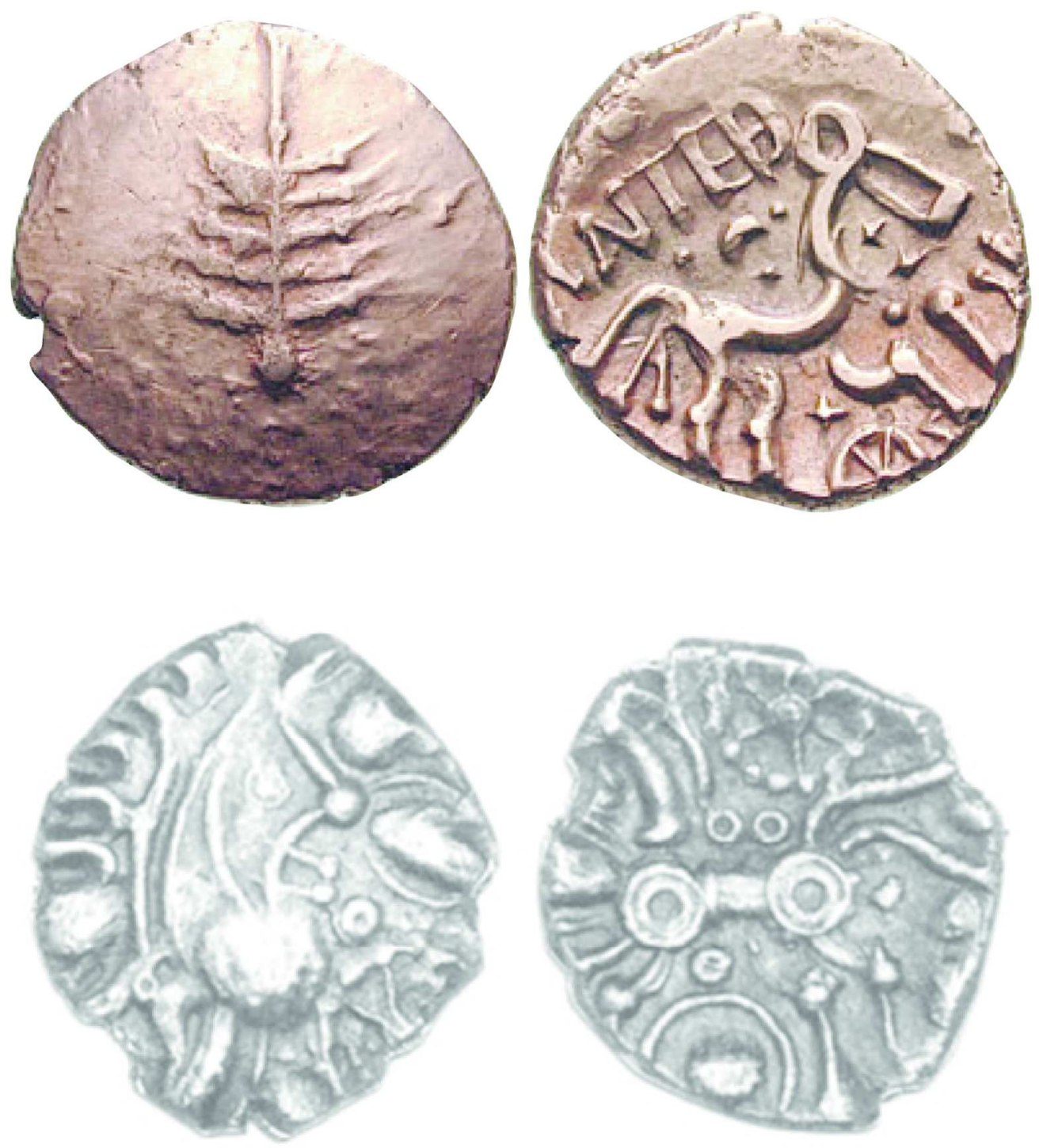

Above: Inscribed gold stater with wheel beneath horse (ABC 2066; CCI-011989). Below: Silver unit with wheel above horse (ABC 2122; CCI-981052)

$141 \times 157 \mathrm{~mm}(300 \times 300 \mathrm{DPI})$ 

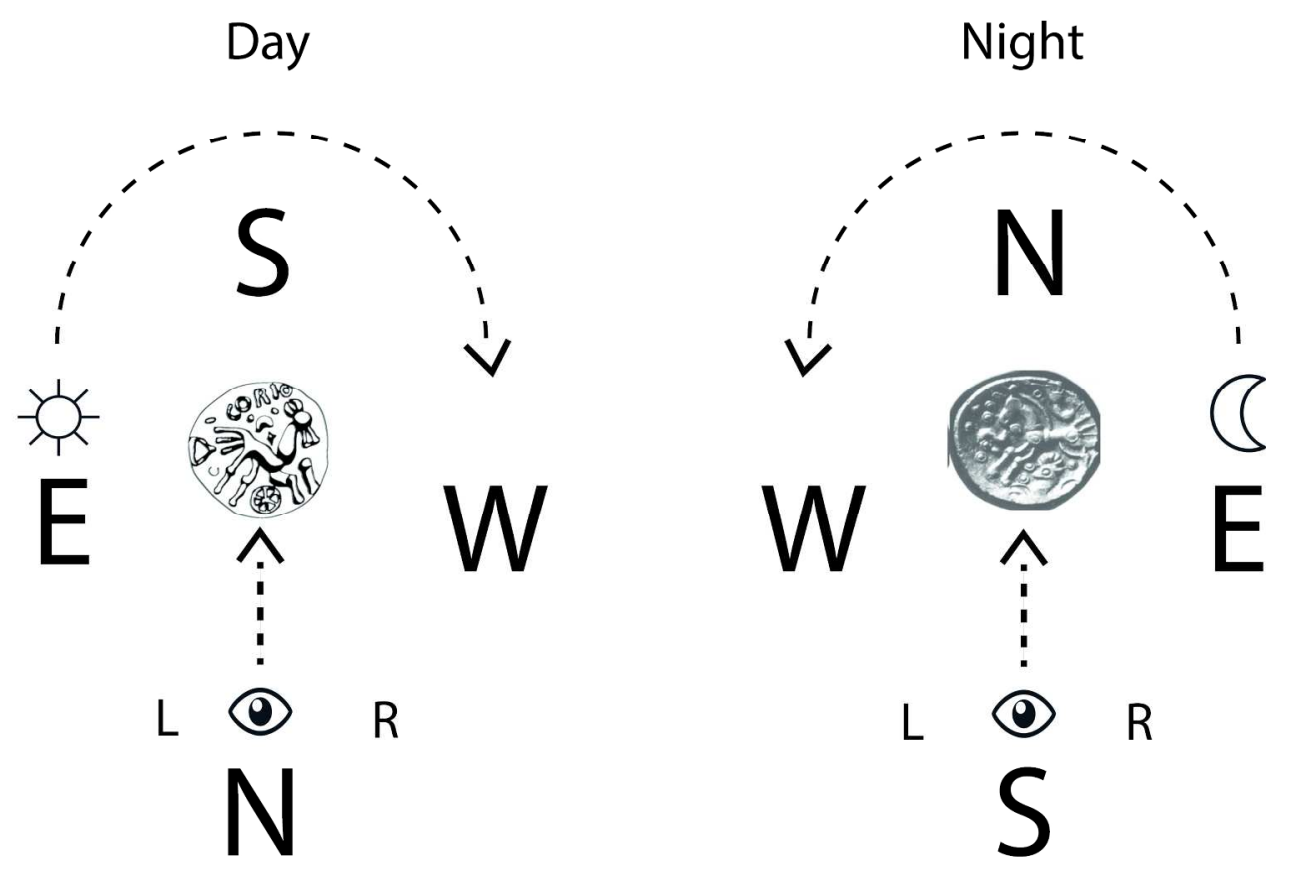

Schematic diagram showing association of day and night in relation to the direction of horse, cardinal points and therefore also the perspective the coin would be viewed from.

$215 \times 144 \mathrm{~mm}(300 \times 300 \mathrm{DPI})$ 


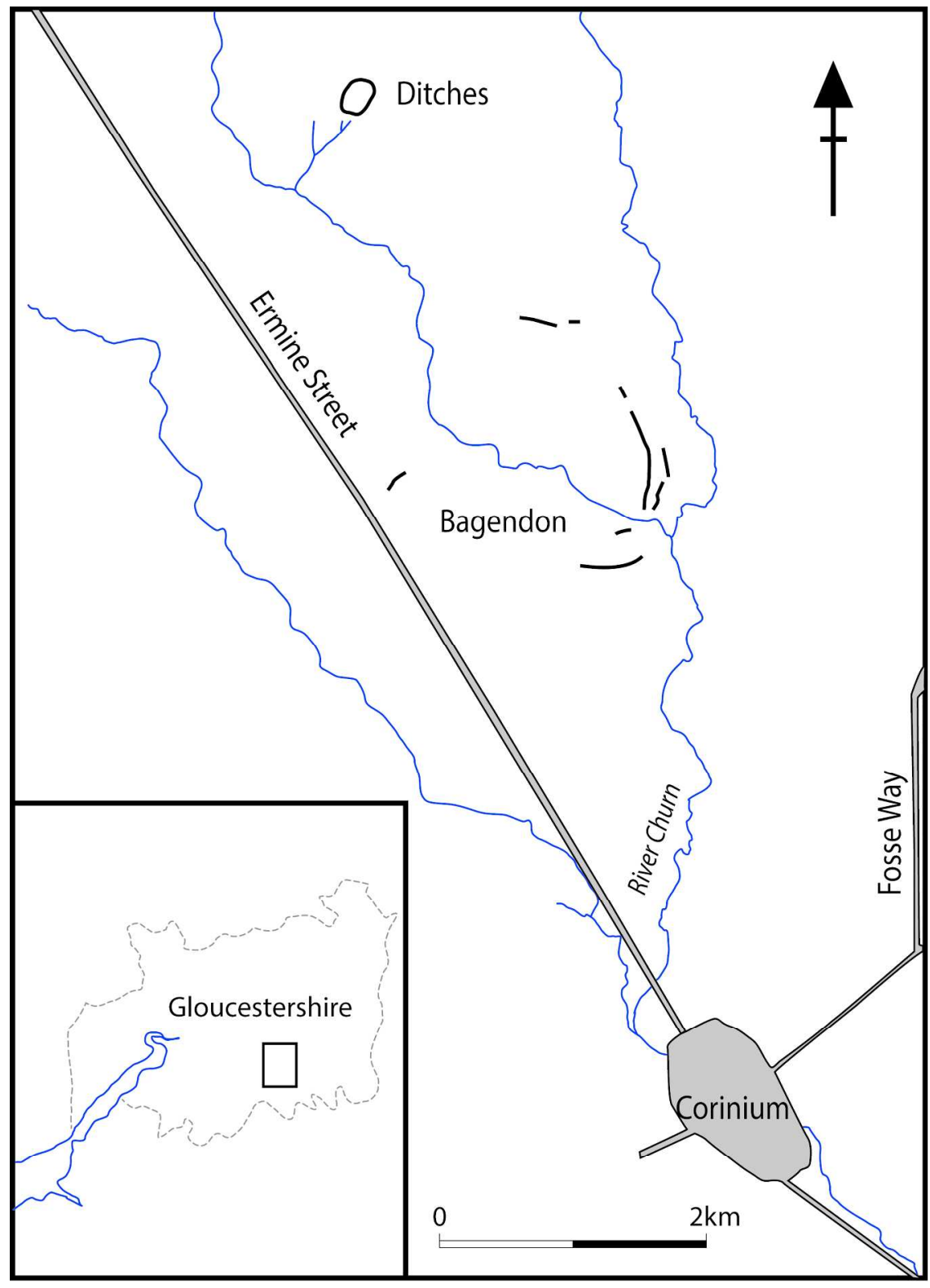

Map to show landscape context of Bagendon and Ditches hillfort (after Trow 1988, 20) $182 \times 252 \mathrm{~mm}(300 \times 300 \mathrm{DPI})$ 